Article

\title{
Geology and Age Constraints on the Origin of the Intrusion-Related, Sheeted Vein-Type Åkerberg Gold Deposit, Skellefte District, Sweden
}

\author{
Kjell Billström $^{1}{ }^{1}$, Benny Mattson ${ }^{2}$, Ulf Söderlund ${ }^{1,3}$, Hans Årebäck ${ }^{2}$ and Curt Broman ${ }^{4}$ \\ 1 Laboratory for Isotope Geology, Swedish Museum of Natural History, P.O. Box 50007, \\ Stockholm 10405, Sweden \\ 2 Boliden Mineral AB, Boliden 93681, Sweden; E-Mails: benny.mattson@ boliden.com (B.M.); \\ hans.areback@boliden.com (H.Å.) \\ 3 Department of Geology, Lund University, Sölvegatan 12, Lund SE-22362, Sweden; \\ E-Mail: ulf.soderlund@geol.lu.se \\ 4 Department of Geological Sciences, Stockholm University, Stockholm 10691, Sweden; \\ E-Mail: curt.broman@geo.su.se \\ * Author to whom correspondence should be addressed; E-Mail: kjell.billstrom@ nrm.se; \\ Tel.: +46-8-5195-5128; Fax: +46-8-5195-5130.
}

Received: 11 September 2012; in revised form: 21 October 2012 / Accepted: 23 October 2012 /

Published: 31 October 2012

\begin{abstract}
The Early Proterozoic ( 1.9 Ga) Skellefte mining district in northern Sweden hosts abundant base metal deposits, but there are also gold-only deposits. The Åkerberg gold ore is unusual given the noted lack of alteration, a scarcity of sulfides and gold associated with thin (mm-cm wide) parallel quartz veins hosted in a gabbro. The gold content is positively correlated with the density of quartz veins, but gold often occurs between veins and also in parts of the gabbro where there is no veining. The gabbro is intruded by a granodiorite and associated pegmatite bodies, and $\mathrm{U}-\mathrm{Pb}$ dating of zircon and baddeleyite suggest that these lithologies developed close in time at around $1.88 \mathrm{Ga}$ ago. There are no primary inclusions in quartz veins, but different types of secondary aqueous inclusions occur. The Åkerberg ore is interpreted as a sheeted vein complex, with veins constrained to tensional cracks induced when a granodioritic magma intruded the competent, sheet-like gabbro intrusion. It is suggested that unmixing of the felsic magma also produced pegmatite bodies and a gel-like melt which invaded fractures in the gabbro
\end{abstract}


and deposited silica. In a comparison, the Åkerberg ore shares many characteristics with the intrusion-related style of gold mineralizations.

Key words: Skellefte district; gold ore; sheeted vein complex; U-Pb dating; fluid inclusions; intrusion-related style

\section{Introduction}

The Skellefte mining district is a major metal producer in northern Sweden (Figure 1), and about $110 \mathrm{Mt}$ (million tons) of VMS (volcanic massive sulfide) type of ore have been produced since the 1920s. Many of these base metal ores carry gold and silver as important by-products [1]. In particular, the complex Boliden deposit was gold-rich with an average gold grade of $15.9 \mathrm{~g} / \mathrm{ton}$ and a total ore tonnage of $8.3 \mathrm{Mt}$. Gold in massive ore settings has been interpreted as introduced synchronously with the base metals [2] and occasionally to be of epithermal origin [3]. Apart from forming an important constituent in massive sulfide ore deposits, gold is also the single metal of economic interest in a number of epigenetic, quartz vein deposits in the Skellefte mining district and its immediate surroundings. Some of these deposits are spatially connected with granitoids, whereas others are hosted by greywacke-dominated lithologies. These gold-associated rocks were mainly emplaced in the 1.9-1.8 Ga time interval during the so called Svecofennian orogeny, and as such constitute part of the Fennoscandian shield [4].

Although intense prospecting for gold has been conducted during the last few decades in northern Sweden, relatively few comprehensive studies dedicated to gold-only deposits in the Skellefte ore district have been carried out. Among the intrusion-hosted type of deposits, geological descriptions were reported by Björkdal [5-7] and Storklinten [8,9] in the eastern part of the Skellefte district, and by Älgträsk $[10,11]$ in the southern margin of the Jörn granitoid complex. Other relevant papers treat intrusive-associated mineralizations from Vinliden $[8,12,13]$, and other sites in the Vindel-Gransele area [14] in the westernmost part. Skäggträskberget and Grundfors in the southern part constitute sediment-hosted mineralizations $[15,16]$. There are also a number of arsenopyrite-rich orogenic gold deposits in the Lycksele-Storuman ore district (also known as the Gold Line), located west of the Skellefte district. The former ore district is basically a 40-50 km wide zone that stretches NW-SE in a region west of the towns of Lycksele and Storuman (Figure 1), where late-Svecofennian Revsund granites and metasedimentary rocks dominate. The Svartliden deposit [17] has been in production since 2004, and significant mineral resources are defined also at Fäboliden [18].

The classification of gold deposits is a matter of debate and one reason for this is the overlapping characteristics proposed to define specific genetic types of gold ore. For instance, it may be hard to separate "orogenic" from "intrusion-related" gold deposits [19-21], in particular if different events are superimposed upon one another. This point has been addressed for $\mathrm{Cu}-\mathrm{Au}$ mineralizations in the northernmost part of the Fennoscandian shield [22]. Another matter of controversy may be the timing of gold deposition which is an unresolved issue in, e.g., the Björkdal gold deposit [6,7]. 
Figure 1. Geology of the Skellefte district; inset map = Fennoscandia. Added to the map are symbols for gold and VMS occurrences $(\ddot{\mathrm{Al}} \mathrm{l}=$ Älgträsk, Bd = Björkdal, Bol = Boliden, $\mathrm{Gr}=$ Grundfors, $\mathrm{Sk}=$ Skäggträskberget, $\mathrm{St}=$ Storklinten; note that certain of the mineralizations mentioned in the text fall outside the map area. Dotted lines outline the SE part of the Lycksele-Storuman ore district (LSOD); whereas the stippled lines indicate the extension of the Skellefte massive ore-bearing district. Abbreviations in inset map: $\mathrm{BB}=$ Bothnian basin. The rectangular box shows the map area of Figure 2.

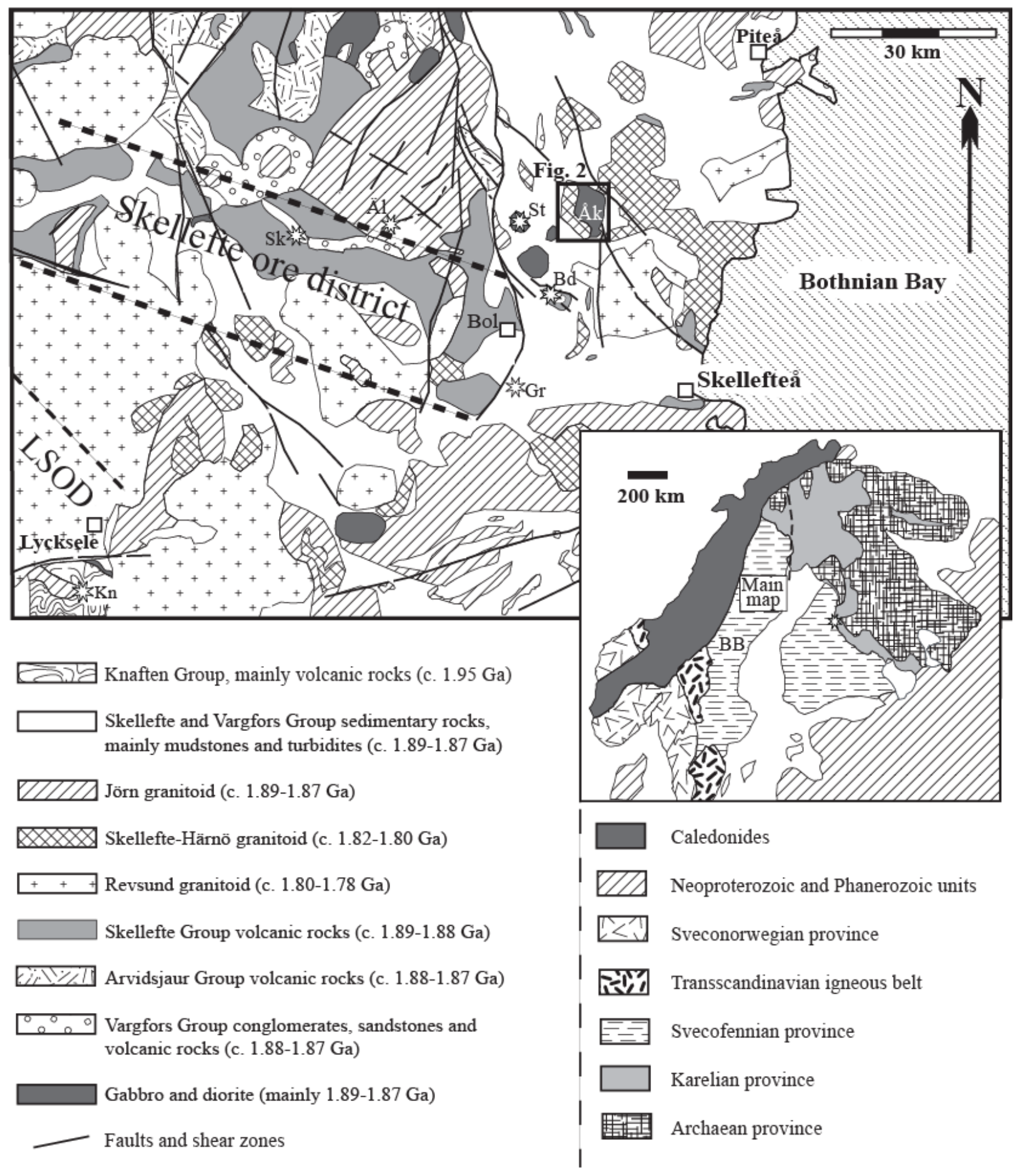

is Gold deposit $\square$ Town 
Figure 2. Geology of the Åkerberg area (modified after Mattson and Lundstam [23]). The two gabbro rock specimens and the granodiorite selected for dating were taken from localities in a limited area just north of the gold mine. A locally used grid is shown on the map. The center of the outlined gold mine corresponds approximately to coordinates N722455 and E173250 in the Swedish National Grid, RT90.
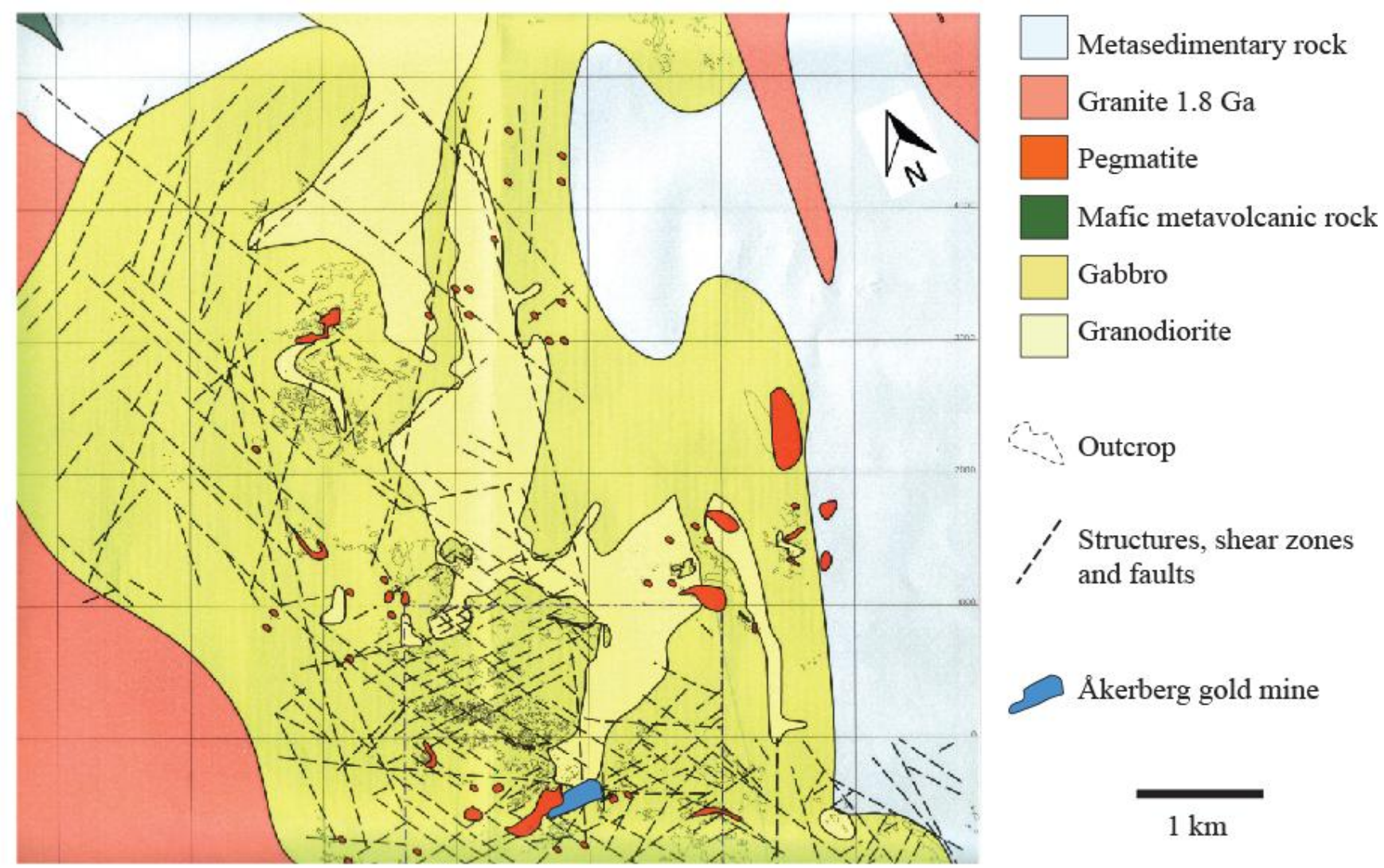

The study of the Åkerberg deposit, situated approximately $35 \mathrm{~km} \mathrm{NW}$ of Skellefteå, may help to shed further light on these issues. This gold mine was operated by Boliden Mineral AB during the years 1991-2003 and approximately 1.5 Mt of ore with an average grade of $3.1 \mathrm{Au}$ g/ton (and $3.2 \mathrm{~g} /$ ton of silver) was mined. Apart from unpublished company reports, no proper geological documentation exists for this deposit. The Åkerberg gold ore has some features which makes it unique among gold mineralizations in the Fennoscandian shield. These include a scarcity in sulfides, a lack of significant alteration, and a spatial association of gold with a dense network of thin quartz veinlets hosted by a gabbro. Apparently, only few other deposits world-wide (e.g., the Mokskro deposit in Bohemia) have similar characteristics and it is the scope of this paper to provide a basic geological description of the Åkerberg gold ore and to discuss its genesis. The inferred genetic and field relationships between a granodiorite and an old generation of (steeply dipping) pegmatites is of fundamental importance in the suggested ore genetic model. Particularly, attention will be brought to the mechanisms of vein formation and the timing of gold introduction in relation to the crustal evolution of the ore-bearing area. To help achieve these goals field data, U-Pb age results for two of the ore-associated rocks (gabbro and granodiorite) and preliminary fluid inclusion data will be presented. 


\section{Results and Discussion}

The Akerberg deposit is found in a marginal basin of the volcanic arc making up the Skellefte district [24] in northern Sweden. The term "Skellefte district" is commonly used for a region which is defined by the presence of base metal deposits and if this definition is strictly adopted it follows that Åkerberg (and also the Björkdal gold ore) is located outside the Skellefte district proper. The Skellefte district forms a NW-SE trending belt comprising early Proterozoic rocks (Figure 1). The district is delineated by juvenile metavolcanics, and its geology has been dealt with in numerous papers with excellent summaries presented by Allen et al. [1] and Kathol \& Weihed [25]. The bedrock adjacent to Åkerberg is dominated by 1.9-1.8 Ga old Svecofennian supracrustal rocks and granitoids of different generations. Supracrustal rocks are typically divided into the Bothnian Supergroup, consisting mainly of metagreywackes of the Bothnian Basin, and the Skellefte, Arvidsjaur and Vargfors Groups [1].

\subsection{Geology of the Akerberg Area}

The area surrounding the Åkerberg deposit is dominated by metasedimentary rocks of the Bothnian Group. Metavolcanic rocks of the Skellefte Group, which make up a conspicuous lithological unit in the main Skellefte district, are essentially missing in the study area. In the proximity of the Åkerberg ore, a granodiorite intrusion and pegmatite bodies are emplaced within a gabbro which hosts the gold ore (Figure 2). Adjoining rocks are granitoids of the $1.8 \mathrm{Ga}$ Skellefte-Härnö suite being intrusive into metasedimentary rocks of the Bothnian group, and further away also $1.8 \mathrm{Ga}$ Revsund granitoids occur. The well-studied Jörn complex [26], comprising four intrusive phases of granitoids (GI to GIV) which span a minimum age interval from around 1890 to $1860 \mathrm{Ma}$ [27,28], is located west of Åkerberg. All supracrustal rocks, and partly the granitoids, have been subjected to a regional metamorphic event, but for simplicity the prefix meta- is not used below.

Unlike the common situation in the Skelleft district proper, rock exposures are plentiful in the Åkerberg area and in combination with prospecting-driven drilling campaigns this helps to erect a good picture of the surface geology. Following an exploration report by Boliden Mineral AB [23] the geology can be described as follows. The gabbro forms a large (about $10 \mathrm{~km}$ long along a north-south direction) layered intrusion which also constitutes the host to the gold ore. The magmatic layering, often dipping approximately $50^{\circ}$, but locally being more flat, is relatively diffuse and is defined by variations in mineralogical composition and by the parallel orientation of plagioclase. Geophysical data suggest that the gabbro has the shape of a shallow sheet [29], and it has been mapped as an early orogenic intrusion, i.e., emplaced in the 1.89-1.87 Ga interval [29]. Grain size is variable, ranging from a coarse-grained, feldspar-rich rock of dioritic composition to a medium-grained, dark-green gabbroic variety that is quite homogeneous with clusters of biotite. In the ore zone the gabbro tends to be richer in quartz. Certain layers are more fine-grained with a dominantly mafic composition, and sulfide-bearing layers are also found. Xenoliths of sedimentary rocks occur in places. Feldspars are locally altered to albite and this is particularly obvious in association with quartz veins. At the contact to sedimentary rocks, chlorite alteration becomes obvious and an orientation of biotite flakes gives rise to a pronounced foliation. In sheared parts of the gabbro, all primary textures might be lost. Pyrite, and to a lesser extent pyrrhotite and arsenopyrite, occur as traces in the rock, although obvious clusters of sulfides and even small sulfide veins are not uncommon. Besides, feldspar and actinolite may occur as 
mono-mineralic 1-2 mm wide veins, and are locally quite common. Quartz veins and pegmatite dykes are also locally abundant, whilst aplite veins are relatively rare. Scheelite is found in quartz-feldspar veins, but does also occur randomly in the gabbroic rock. There are also mafic dykes, between $15 \mathrm{~cm}$ and $3 \mathrm{~m}$ in width, which cross-cut both the gabbro and the granodiorite. These dykes are usually homogeneous and fine to medium grained with sharp contacts to their host rocks, and contain calcite veins and traces of scheelite.

The granodiorite is medium-grained, granoblastic, light grey with a homogeneous and basically isotropic structure. The granodiorite intrudes the gabbro and the contact between the rocks could be either sharp or gradational with a shallow dip. It forms an elongate intrusion in the interior of the gabbro body, and also outcrops as small, individual lenses in the gabbro. Dominant minerals are quartz, feldspar and biotite. Occasionally, the presence of 1-2 mm large feldspars transforms the rock to a spotty, weakly porphyritic variety. The latter rock facies may be dark grey and is often connected to crush zones. Opaques include impregnations of arsenopyrite and traces of pyrite. In addition, a reddish rock type exhibiting the same mineralogy occurs in places. Based on the geochemistry of the granodiorite, it has features in common with S-type granites [30], and a geochemical resemblance can be noted with gold-associated porphyries at Vinliden and Storklinten [24].

Noteworthy, its field characteristics are very similar to those of the $1877 \pm 2$ Ma Stavaträsk dioritic granitoid [31] occurring some ten kilometers west of Åkerberg. On geochemical grounds, the Stavaträsk intrusion has been classified as a GII granodiorite-granite variety ([25] and references therein) which has been dated at approximately $1875 \mathrm{Ma}$ at several places [26,27]. Quartz veinlets, 1-2 mm wide, and seemingly of a similar type to those found in the gabbro, occur here and there in the granodiorite. In places, such quartz veinlets are cutting the granodioritic rock, whereas the opposite is observed at other locations (Figure 3), suggesting that gold-bearing quartz veins are temporarily linked with the intrusion of the granodiorite. Minor feldspar veins, of which some are scheelite-bearing, are locally abundant and scheelite does also form stringers in the granodiorite. A pervasive alteration is seen to locally transform the granodiorite into a rock with almost no original textures preserved.

Sedimentary rocks in the study area are considered to belong to the Bothnian Group [29]. At Akkerberg these units overlie the volcanic rocks of the Skellefte Group and constitute the main lithology east of the gabbro. Greywackes dominate and display occasionally well-developed sedimentary structures, such as cross-bedding, graded bedding, load casts and convolute folds. Locally, pyrite and pyrrhotite form prominent sulfide-layers in sedimentary rocks which are intruded by the gabbro. Deformed sediment clasts occur here and there in the gabbro.

Two different types of pegmatites may be distinguished. The first is made up of whitish to reddish, steeply dipping dikes with a coarse- to very coarse-grained simple mineralogy dominated by quartz, feldspar, biotite and tourmaline. This type forms numerous small bodies occurring both within the gabbro and the granodiorite, and on the geological map such bodies tend to be concentrated to the vicinity of granodiorite outcrops (Figure 2). The second type comprises sub-horizontal bodies and has a more complex chemistry with muscovite and garnet in addition to the above mentioned phases. Near the ore zone it makes up a single, up to $30 \mathrm{~m}$ thick, sheet which adjoins the gold ore and has a sub-horizontal dip of $5-10^{\circ} \mathrm{N}$. It has a surface dimension of $1000 \times(100-200 \mathrm{~m})$ [32] and partly caps the gabbro. This two-mica rock is partly faulted to the south and may show a subhorizontal layering within coarser parts, whereas other parts are more granitic in appearance. When approaching the ore 
zone, it changes into a complex Li-Cs-Ta (LCT)-type [33], comprising, e.g., Li-Cs minerals (lepidolite, spodumene and pollucite), several tourmaline varieties, allemontite, topaz, amblygonite, cassiterite, columbite and microlite that occur in vein-like zones or masses. This mineral association is comparable to the parageneses of LCT-type pegmatites in Sweden, found, e.g., at Varuträsk about $40 \mathrm{~km} \mathrm{~S}$ of Åkerberg where columbite dating yielded a $1775 \pm 11 \mathrm{Ma}$ age [34]. Considering the difference in mineralogy and structural setting it appears that the described pegmatite types define two different generations which pre- and post-date the regional metamorphism, respectively. This view is strengthened by their relationship to ore-bearing quartz veins. The first type with a simple mineralogy is generally being cross-cut by quartz veins, whilst the opposite is always true for the flat-lying second type of pegmatite.

Figure 3. (a) Two semi-parallel vein-shaped lenses of granodiorite, of varying width, truncating a weathered gabbro surface; the pen next to one of the lenses is $9 \mathrm{~cm}$ long. The gabbro also carries numerous quartz veins (trending along a near-vertical direction in the image), which mainly stop at granodiorite lenses, and certain veins are offset by a few centimeters; (b) Quartz veins that dominantly transect a near-horizontal granodiorite lens enclosed in the gabbro (scale as in (a)).

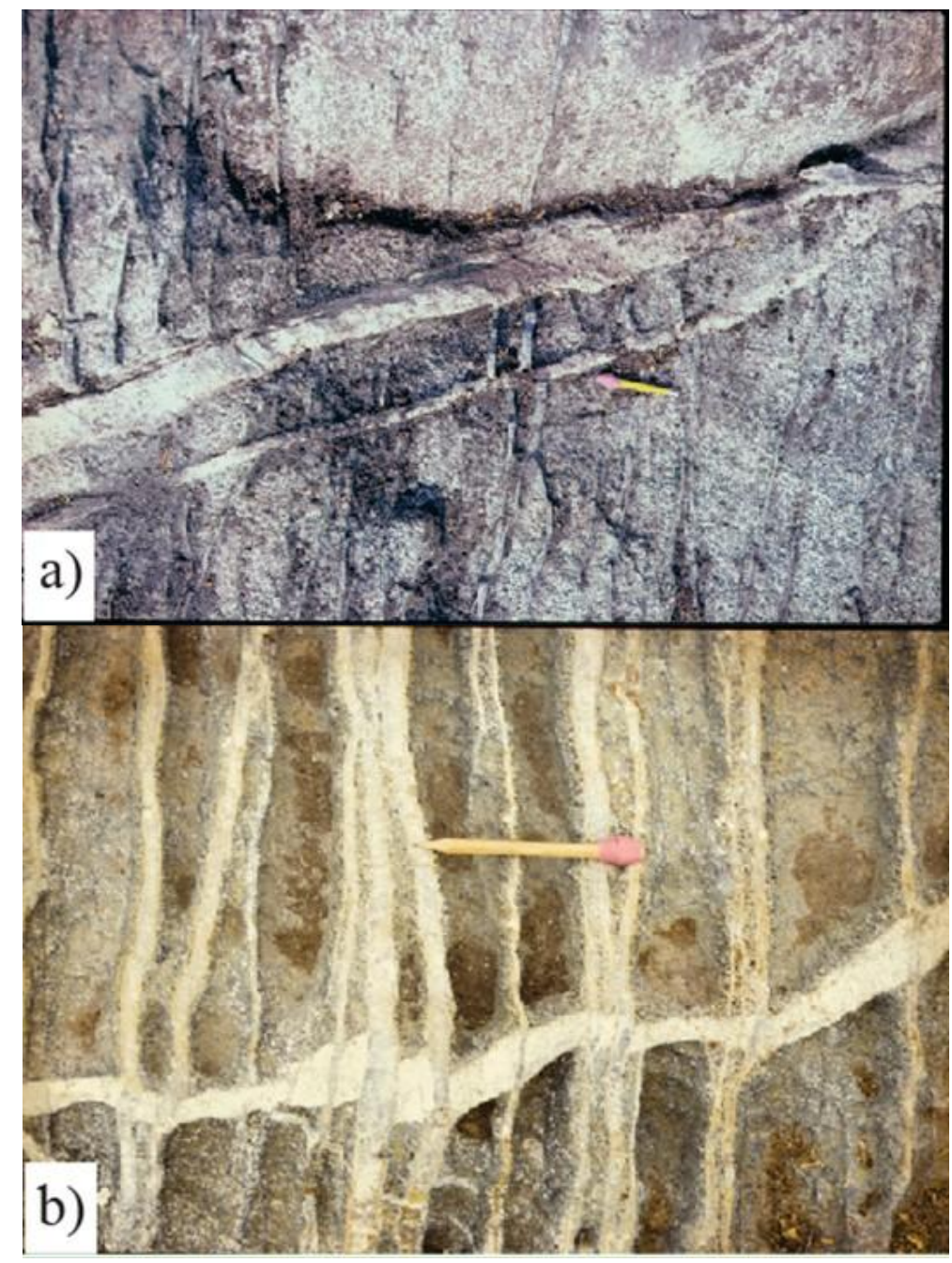




\subsection{The Ore and Occurrence of Gold at Akerberg}

Gold mineralization in the overall Skellefte district are of different types and occur in different geological environments [11,16,35-38]. Generally, many gold-only mineralization can be described as structurally controlled orogenic gold deposits. Typically, gold is linked to arrays of quartz veins of different trends and widths (cm to m-scale) and is found in strongly hydrothermally altered zones hosted by sedimentary and volcanic rocks. In contrast, the gold ore at Åkerberg shows an atypical style; gold is concentrated to the vicinity of narrow, gabbro-hosted sub-parallel quartz veins or veinlets, typically being 1-2 mm wide. These veins often widen at depth where they occasionally may carry gold grades up to $50 \mathrm{ppm}$. A conspicuous feature is an about $300 \mathrm{~m}$ wide halo, displaying only very minor quartz veining, that contains erratically distributed sub-zones with $0.1-0.5 \mathrm{ppm} \mathrm{Au}$. The mined ore is part of this halo and is defined by an approximately $10 \mathrm{~m}$, occasionally reaching $30 \mathrm{~m}$, wide and $350 \mathrm{~m}$ long zone with essentially vertical E-W trending quartz veins. Basically, the mined ore is delimited by two mylonite zones. The ore could be followed to a depth of $150 \mathrm{~m}$ in the western part where it is displaced by the complex pegmatite, whereas the eastern part is truncated by the intruding granodiorite. There exists no detailed map of the mined area which has a rather uniform and simple appearance defined by quartz veins set in the gabbro, and a typical exposure of the E-W ore zone is shown in Figure 4. Quartz veins have a strike and dip that is similar to, but yet distinct from, that of the mylonite zones. In the mined area, gold-associated veins are typically densely spaced, and sometimes more than fifty veins per meter could be distinguished (Figure 5). Furthermore, veins are continuous and could occasionally be followed for hundreds of meters along strike. Generally, such veins dip steeply to the north and occur in a parallel to sub-parallel fashion which mirrors that of an en echelon arrangement. The developed quartz veins or veinlets constitute a sheeted vein complex, which is suggesting that veins did not form within shear structures but are due to tensional fracturing.

Figure 4. Mineralised gabbro outcrop (compass for scale).

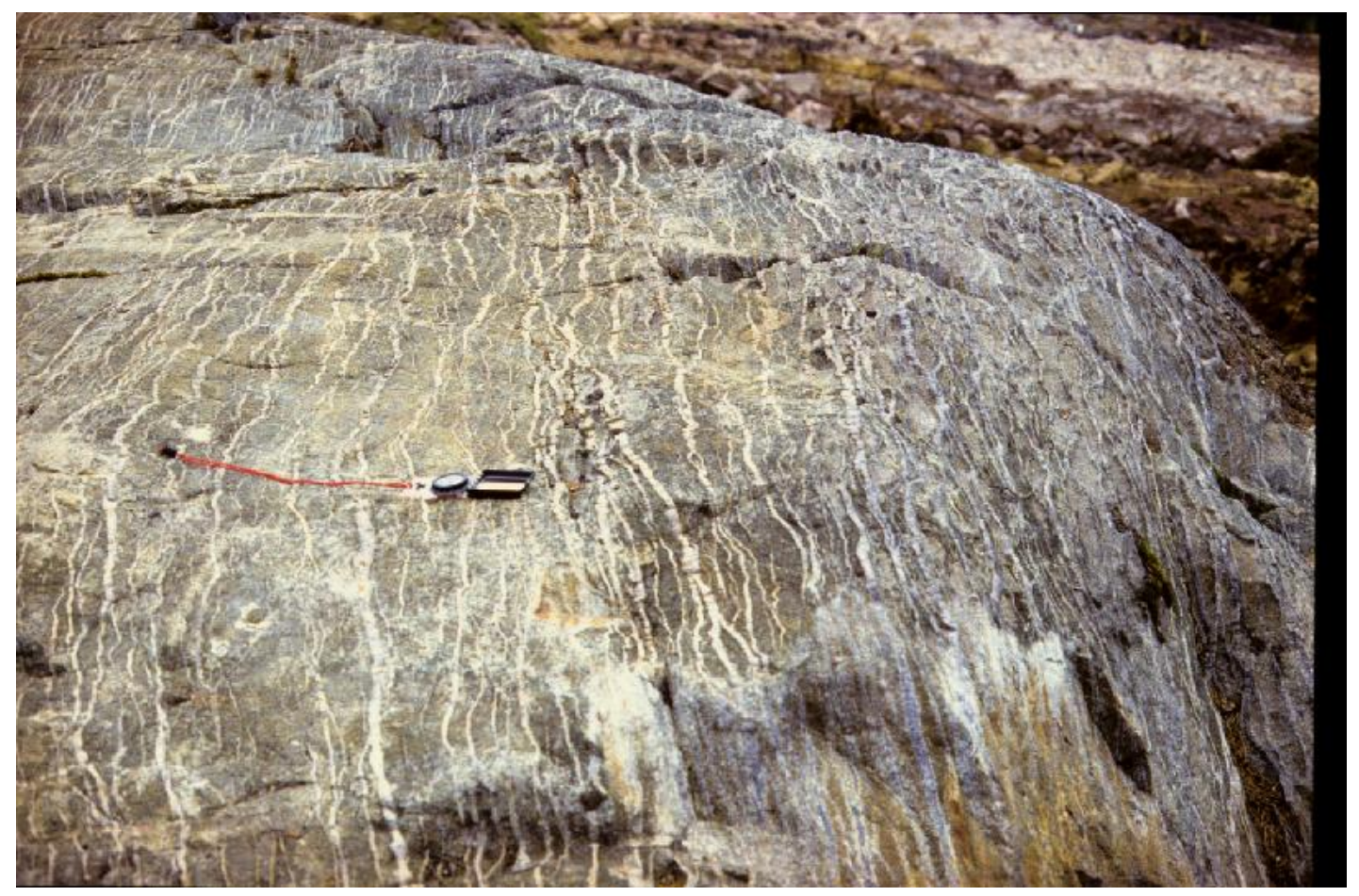


Figure 5. Vertical profile showing that inner parts of mineralised zones typically are characterized by an elevated number of quartz veins/meter.

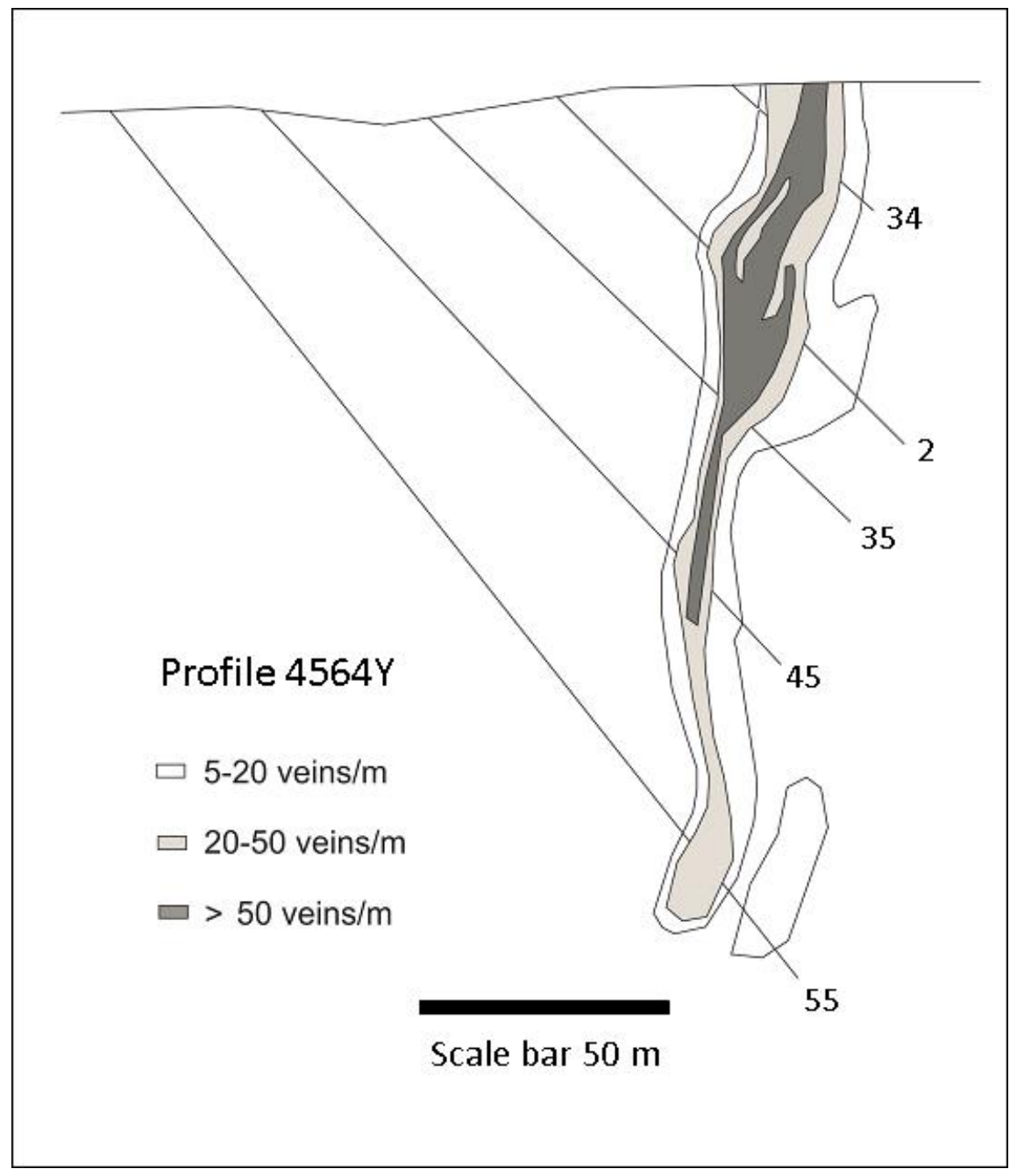

Alteration is very minor involving mainly albitisation of feldspar in the gabbro. Within the quartz veins, amphiboles form thin schlieren that often run parallel with the vein contact (Figure 6). In places with a high frequency of cross-cutting microfractures, amphiboles at the border of the quartz veins are slightly altered as seen by a very thin green-brownish Fe-rich chlorite rim along the quartz-amphibole contact (Figure 6). Minor pyrrhotite and rare chalcopyrite are occasionally found associated with this alteration. However, a spatial association between gold and veinlets of pyrrhotite and actinolite is only rarely noted. Thus, gold-associated quartz veinlets are always low in sulfides (typically less than 1\%) comprising pyrrhotite with some pyrite, and occasionally ilmenite. However, there is a clear correlation between the density of quartz veins and the gold grade (Figures 5 and 7). Scheelite appears to be the only phase that strictly follows gold, and possibly also tourmaline is a gold-associated phase. Gold is very fine-grained, typically in the order of 10-15 $\mu \mathrm{m}$, and macroscopic gold can normally only be seen on sawed surfaces after having been smeared out. Microscopic studies ([39]; this study) show that gold occurs associated with different minerals, such as feldspar, scheelite and sphalerite, but is quite rare in quartz. Gold is found both along grain boundaries and in intra-grain settings at sites within and near to quartz veinlets. It is also evident that quartz vein systems have different directions in different parts of the gabbro, and that large zones in the gabbro body have anomalous, sub-ppm 
contents of gold. For instance, one limited area is characterized by gold-rich (up to $15 \mathrm{ppm}$ ) relatively wide (cm-dm) quartz veins following a NW-SE direction. Besides, gold is also locally occurring in a homogeneous dark grey gabbro type, as well as in finer-grained and more heterogeneous parts of the gabbro. In these settings, gold is not accompanied by quartz veinlets. Furthermore, enhanced gold levels are found in the granodiorite and sometimes, but not always, quartz veins are present at such sites. Sulfides are seldom visible in these settings. Wherever the granodiorite becomes more altered some arsenopyrite and pyrite occur and quartz veinlets are seen at most places. Finally, the mineralogically simple pegmatite is as well locally anomalous in gold. There are also larger, cm- to $\mathrm{dm}$-wide, arsenopyrite-bearing N-S trending quartz veins in parts of the gabbro and such veins are also found within metasedimentary rocks.

Figure 6. (A) Amphibole along vein contacts in quartz and (B) an illustration of a schlieren-like appearance of amphibole.
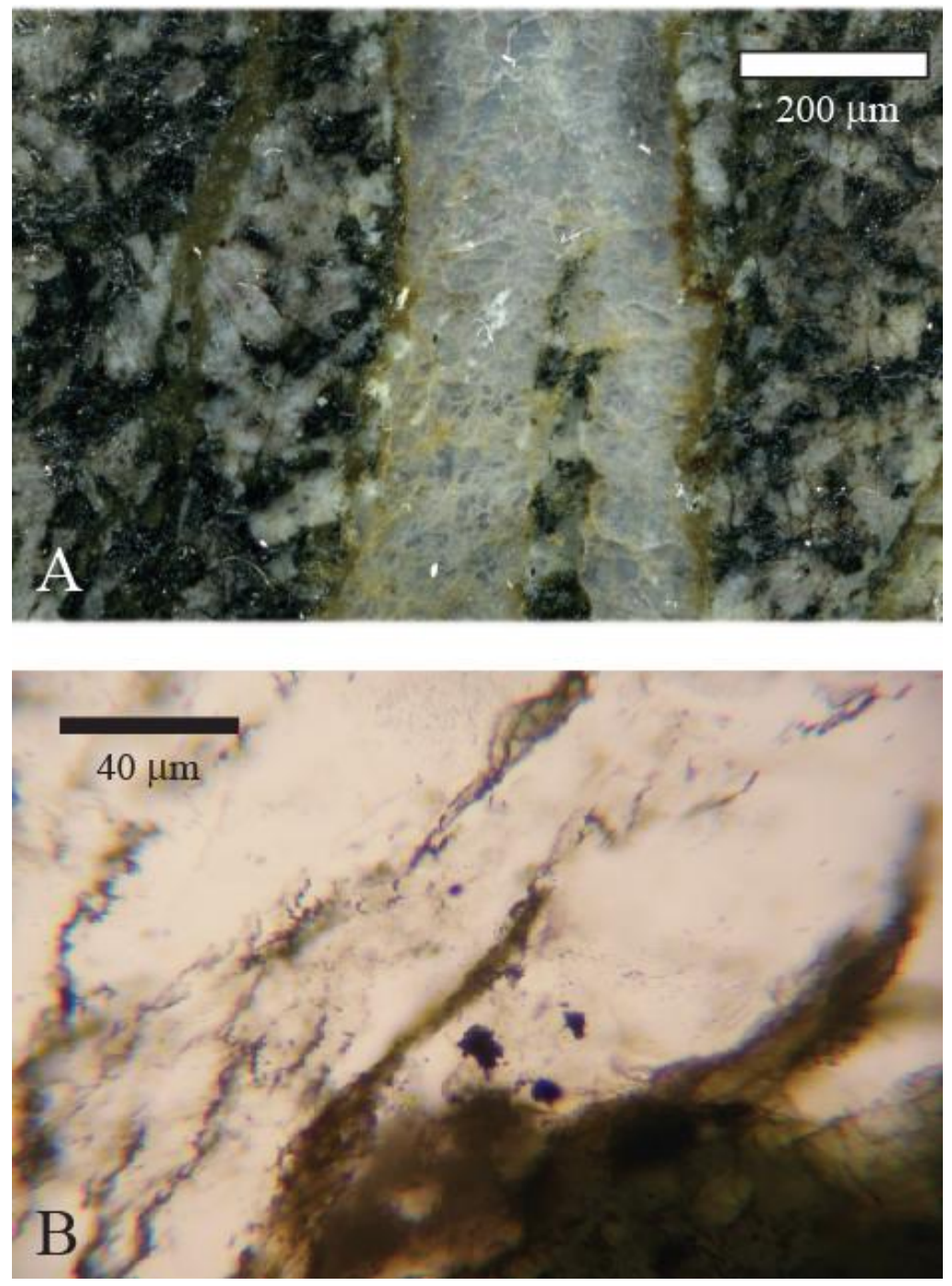
Figure 7. Gold zonation along a vertical profile.

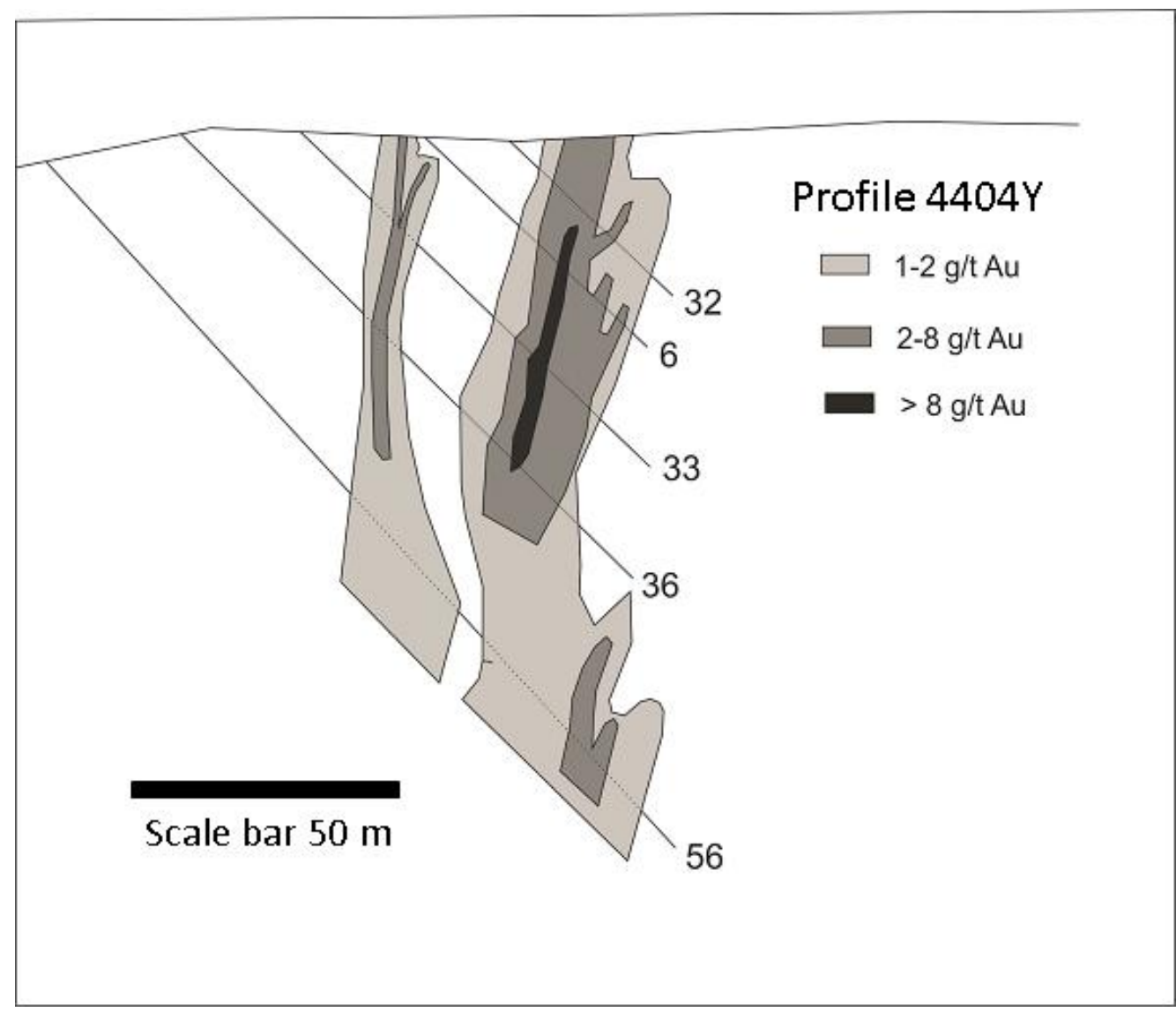

\subsection{Local Deformation and Metamorphism}

Previous field work aiming to establish the deformational history has mainly focused on the Skellefte district proper, and certain temporal constraints are indicated in Figure 8. On a regional scale, deformation has been interpreted to comprise two regional fold phases preceded by a possibly synvolcanic event producing a vague, mineral lineation [1]. The first regional (D2) phase resulted in upright, tight to isoclinal folds and related shear zones. These structures are typically not seen affecting Revsund granitoid rocks why D2 must pre-date $\sim 1.8 \mathrm{Ga}$. The second regional (D3) event produced open folds and is connected with N-S shear zones that were active at, or slightly later than, $1.8 \mathrm{Ga}$ [40]. The kinematics of these latter shear zones suggest an E-W shortening. However, relatively little is known of the overall deformation history of the Skellefte district, and there are evidence reported for an early $1.88-1.86 \mathrm{Ga}$ (D1) deformation in the eastern parts [31,41-43].

Studies of metamorphism and deformation have not been undertaken in any detail in the study area around the Akerberg ore, and it is not obvious to make comparisons with the main sulfide ore-bearing Skellefte district given the differences in geological setting. However, it is clear from the evidence presented below that the general study area has suffered a multi-stage history. Generally, the intensity of the metamorphism increases eastwards in the region, and rocks east of Åkerberg may be thoroughly migmatised. Metamorphism is approximately of lower amphibolite facies in the study area, and sedimentary rocks are partly recrystallised [29]. A set of N-S shear zones appears to have affected all rocks in the area around, and north of, the Åkerberg ore. Because also young pegmatites spatially 
associated with $\geq 1.8 \mathrm{Ga}$ Skellefte granites are affected by shearing it is implied that these movements must be $1.8 \mathrm{Ga}$ or younger. Thus, these zones may be correlated with the second regional metamorphic (D3) event. Moreover, NE-SW shear zones are fairly numerous in the Åkerberg area [29] showing a dextral movement with reference to the horizontal plane of the ore zone and it is suggested that the northern parts have moved upwards relative to the southern parts. However, the NE-SW oriented zones are essentially restricted to the gabbro, suggesting that these could form an older set of deformation structures. A dextral movement is also occasionally seen by the quartz veins in the ore zone. Recent studies of the Jörn complex have revealed that local ductile deformation zones cut the earliest $\leq 1.89 \mathrm{Ga}$ GI generation of Jörn granitoids but such zones are not present in the younger (GII-GIV) 1875 Ma granitoid generations [26]. Actinolite-tremolite occurs as minor veins at Åkerberg, but further to the west actinolite may form conspicuous alteration patterns which have been interpreted as a metamorphic end-product of syn-volcanic alteration processes [29]. Another expression of the tectonic history is the presence of the two mylonitic zones that run parallel with, but slightly discordant to, the ore zone at Akerberg. In view of the tectonic evidence presented above, the hypothesis that the granodiorite at Åkerberg represents a 1875 Ma GII intrusion and the quartz vein-rock interrelationships, the favoured tectonic evolution is as follows: (1) Near the site of its emplacement, the gabbro underwent ductile deformation which created approximately E-W mylonitic zones; (2) close in time to mylonitization, but somewhat later and probably during an ongoing uplift process connected with felsic magmatism, extensional fracturing led to veining of the $\geq 1.88$ Ga gabbro; (3) significantly later, $1.8 \mathrm{Ga}$ regional metamorphism affected the study area, but most of the deformation was taken up in N-S shear zones. Linked to this, the complex two-mica pegmatite intruded.

Figure 8. Cartoon showing the approximate timing for various crustal events and possibly related gold mobilisation in the Skellefte district and its immediate surroundings.

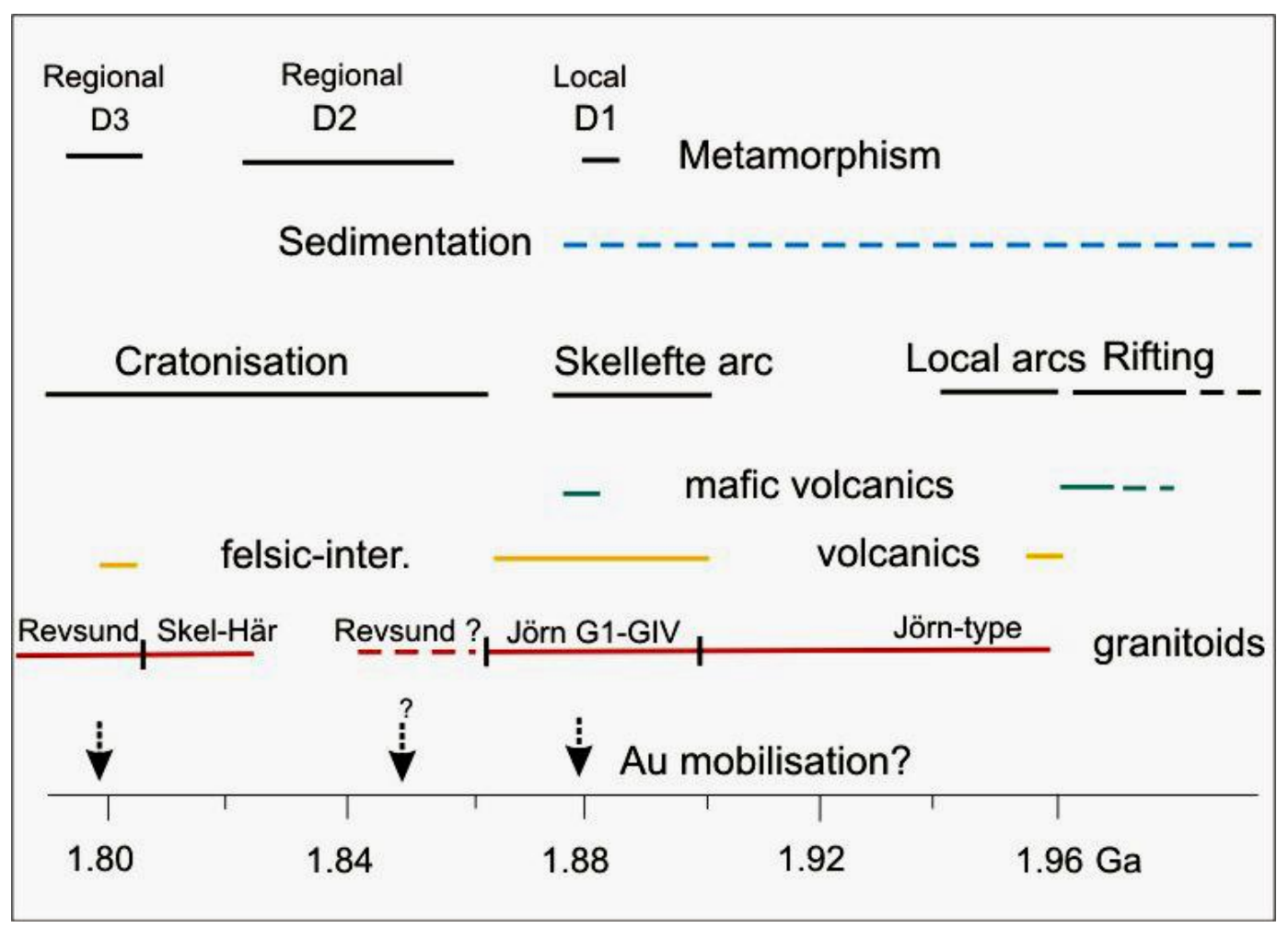




\subsection{Analytical Results}

\subsubsection{U-Pb Dating of the Gabbro}

Altogether 10 SIMS spot analyses, including both cores and rims, were obtained from seven zircon grains from the gabbro (sample 96016; see experimental section) and shown as grey ellipses in Figure 9. Disregarding two imprecise data points (\# 2a and 3c) and the $3 b$ spot (which may comprise a mixture of two age domains), the remaining results tend to define two separate discordias (Table 1, Figure 9). However, it is difficult to relate the individual data to the character of analyzed spots, and for example results of two near-concordant rims (\# 8a and 5a) yielded ${ }^{207} \mathrm{~Pb} /{ }^{206} \mathrm{~Pb}$ ages of $1889 \pm 3$ and $1796 \pm 8 \mathrm{Ma}$, respectively. Neither CL imaging (Figure 10a), nor $\mathrm{Th} / \mathrm{U}$ ratios (range between 0.12-0.52; Table 1) help to confidently separate discrete age populations. Tentatively, analyses of prismatic and cracked grains, and grain tips seem to plot about a younger discordia, whereas analyses yielding the older age are from more subhedral and turbid grains. Regression of data points on one tentative discordia $(n=3)$ yields an age of $1793 \pm 15$ Ma $($ MSWD $=0.95)$, whilst the other inferred discordia $(n=4)$ points to an age of $1889 \pm 6$ Ma $(M S W D=1.5)$. Both regressions yield a similar lower intercept age close to $250 \mathrm{Ma}$ which gives some credit to the choice of data points included in each regression. This age is compatible with indicated lower intercept ages obtained in numerous studies of the early Proterozoic bedrock of Sweden and Finland and has been interpreted as related to uplift processes and associated loss of radiogenic lead during hydrothermal activity [44].

Figure 9. U-Pb concordia diagrams with analytical results for baddeleyite; bd (black symbols in inset, TIMS data) and zircon (grey symbols, SIMS data) separated from the gabbro. For the sake of clarity, the two most discordant zircon data points and one analysis with a large error are omitted.

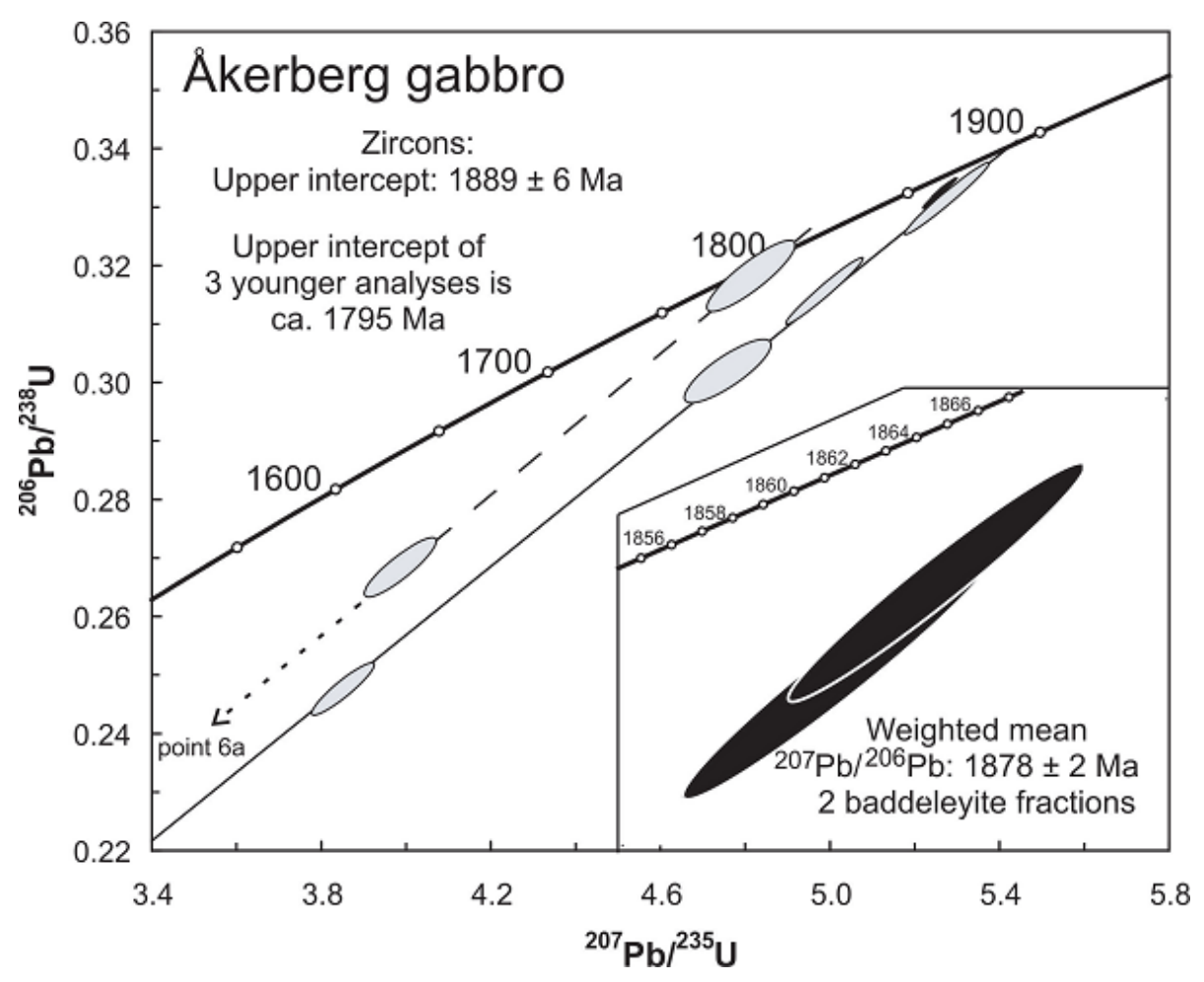


Table 1. Ion microprobe (SIMS) U-Th-Pb isotope data of zircons from a gabbro (96016) and a granodiorite (94002) at Åkerberg.

\begin{tabular}{|c|c|c|c|c|c|c|c|c|c|c|c|c|}
\hline $\begin{array}{c}\text { Grain/ } \\
\text { Spot \# }^{\text {a }}\end{array}$ & $\begin{array}{c}\mathbf{U} \\
\mathbf{p p m}\end{array}$ & $\begin{array}{c}\mathrm{Pb} \\
\mathbf{p p m}\end{array}$ & $\begin{array}{c}\text { Th/ } / \\
\mathbf{U}_{\text {calc }} \mathbf{b}\end{array}$ & $\begin{array}{l}{ }^{206} \mathrm{~Pb} / \\
{ }^{204} \mathrm{~Pb} \\
{ }^{\mathrm{c}}\end{array}$ & $\begin{array}{l}\mathbf{f}_{206} \\
\%^{d}\end{array}$ & $\begin{array}{c}\text { Disc } \\
\%^{\mathrm{e}}\end{array}$ & $\begin{array}{c}{ }^{206} \mathrm{~Pb} / \\
{ }^{238} \mathrm{U} \\
\pm 1 \mathrm{~s} \\
\end{array}$ & $\begin{array}{c}{ }^{207} \mathrm{~Pb} /{ }^{235} \mathrm{U} \\
\pm 1 \mathrm{~s}\end{array}$ & $\begin{array}{c}{ }^{207} \mathrm{~Pb} / \\
{ }^{206} \mathrm{~Pb} \\
\pm 1 \mathrm{~s} \\
\end{array}$ & $\begin{array}{c}{ }^{206} \mathrm{~Pb} / \\
{ }^{238} \mathrm{U} \\
\text { age } \\
\end{array}$ & $\begin{array}{c}{ }^{207} \mathrm{~Pb} / \\
{ }^{235} \mathrm{U} \\
\text { age }\end{array}$ & $\begin{array}{c}{ }^{207} \mathrm{~Pb} / \\
{ }^{206} \mathrm{~Pb} \\
\text { age } \\
\end{array}$ \\
\hline \multicolumn{13}{|c|}{ Granodiorite (session number, n1711) } \\
\hline $1 \mathrm{a}$, cen & 779 & 301 & 0.34 & 70211 & 0.03 & -6.1 & $0.3166 \pm 1.57$ & $5.002 \pm 1.59$ & $0.1146 \pm 0.24$ & 1773 & 1820 & 1873 \\
\hline $2 \mathrm{a}, \mathrm{ed}$ & 174 & 67 & 0.22 & 22820 & 0.08 & -4.0 & $0.3238 \pm 1.57$ & $5.115 \pm 1.67$ & $0.1146 \pm 0.55$ & 1808 & 1839 & 1873 \\
\hline $2 b$, ed & 151 & 59 & 0.21 & 18588 & 0.10 & -3.0 & $0.3302 \pm 1.57$ & $5.259 \pm 1.66$ & $0.1155 \pm 0.54$ & 1839 & 1862 & 1888 \\
\hline $5 \mathrm{a}, \mathrm{ce}$ & 563 & 194 & 0.21 & 10966 & 0.17 & -13.8 & $0.2906 \pm 1.57$ & $4.591 \pm 1.62$ & $0.1146 \pm 0.40$ & 1645 & 1748 & 1873 \\
\hline $7 \mathrm{a}, \mathrm{ce}$ & 406 & 111 & 0.09 & 6761 & 0.28 & -27.8 & $0.2385 \pm 1.57$ & $3.700 \pm 1.63$ & $0.1125 \pm 0.42$ & 1379 & 1571 & 1841 \\
\hline $7 \mathrm{~b}, \mathrm{ce}$ & 485 & 170 & 0.14 & 24516 & 0.08 & -9.9 & $0.3013 \pm 1.58$ & $4.724 \pm 1.61$ & $0.1137 \pm 0.32$ & 1698 & 1772 & 1860 \\
\hline $9 \mathrm{a}$, ed & 936 & 355 & 0.08 & 29203 & 0.06 & -1.3 & $0.3329 \pm 1.38$ & $5.259 \pm 1.41$ & $0.1146 \pm 0.26$ & 1853 & 1862 & 1873 \\
\hline $9 b, c e$ & 477 & 197 & 0.10 & 1734 & 1.08 & 7.9 & $0.3620 \pm 1.39$ & $5.695 \pm 1.44$ & $0.1141 \pm 0.40$ & 1992 & 1931 & 1866 \\
\hline 12a, ed & 95 & 90 & 2.33 & 25640 & 0.07 & 1.7 & $0.5227 \pm 1.40$ & $13.140 \pm 1.50$ & $0.1823 \pm 0.55$ & 2711 & 2690 & 2674 \\
\hline $12 b$, ed & 39 & 32 & 1.58 & 2997 & 0.62 & -1.5 & $0.5016 \pm 1.40$ & $12.451 \pm 1.66$ & $0.1800 \pm 0.89$ & 2621 & 2639 & 2653 \\
\hline $19 \mathrm{a}$, ed & 491 & 190 & 0.27 & 7976 & 0.23 & -5.6 & $0.3231 \pm 1.38$ & $5.174 \pm 1.43$ & $0.1162 \pm 0.37$ & 1805 & 1848 & 1898 \\
\hline \multicolumn{13}{|c|}{ Gabbro (session number, n572) } \\
\hline $2 \mathrm{a}, \mathrm{ce}$ & 1790 & 698 & 0.25 & 471 & 3.97 & -1.4 & $0.3286 \pm 4.70$ & $5.135 \pm 8.17$ & $0.1133 \pm 6.68$ & 1832 & 1842 & 1854 \\
\hline $3 b$, ce & 449 & 122 & 0.35 & 51813 & 0.04 & -29.1 & $0.2181 \pm 0.78$ & $3.181 \pm 0.85$ & $0.1058 \pm 0.34$ & 1272 & 1453 & 1728 \\
\hline $3 c$, tip & 3914 & 523 & 0.12 & 13026 & 0.14 & -51.3 & $0.1151 \pm 3.23$ & $1.385 \pm 3.74$ & $0.0873 \pm 1.89$ & 702 & 883 & 1367 \\
\hline $4 \mathrm{a}$, ce & 2168 & 637 & 0.19 & 143802 & 0.01 & -25.1 & $0.2478 \pm 0.73$ & $3.851 \pm 0.80$ & $0.1127 \pm 0.31$ & 1427 & 1603 & 1844 \\
\hline 5a, tip & 161 & 65 & 0.52 & 139723 & 0.01 & -1.0 & $0.3182 \pm 0.77$ & $4.817 \pm 0.89$ & $0.1098 \pm 0.43$ & 1781 & 1788 & 1796 \\
\hline $5 b, c e$ & 1001 & 320 & 0.24 & 2019 & 0.93 & -14.5 & $0.2686 \pm 0.77$ & $3.986 \pm 0.87$ & $0.1077 \pm 0.40$ & 1533 & 1631 & 1760 \\
\hline $6 a$, co & 1102 & 274 & 0.33 & 12359 & 0.15 & -31.0 & $0.2005 \pm 1.62$ & $2.794 \pm 1.77$ & $0.1011 \pm 0.70$ & 1178 & 1354 & 1644 \\
\hline $7 \mathrm{a}, \mathrm{ce}$ & 450 & 159 & 0.17 & 2629 & 0.71 & -10.3 & $0.3020 \pm 0.73$ & $4.762 \pm 0.88$ & $0.1144 \pm 0.49$ & 1701 & 1778 & 1870 \\
\hline 8a, tip & 2276 & 938 & 0.43 & 61350 & 0.03 & -2.7 & $0.3314 \pm 0.76$ & $5.281 \pm 0.77$ & $0.1156 \pm 0.16$ & 1845 & 1866 & 1889 \\
\hline $8 \mathrm{~b}, \mathrm{ce}$ & 2165 & 825 & 0.30 & 22645 & 0.08 & -6.5 & $0.3156 \pm 0.73$ & $4.992 \pm 0.75$ & $0.1147 \pm 0.16$ & 1768 & 1818 & 1875 \\
\hline
\end{tabular}

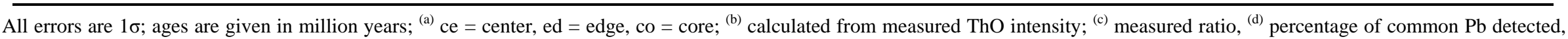
calculated from measured ${ }^{204} \mathrm{~Pb}$ assuming $\mathrm{t}=0 \mathrm{Ma}$ in the Stacey and Kramers model (1975); ${ }^{(\mathrm{e})}$ degree of discordance in percent. 
Figure 10. CL images and ${ }^{207} \mathrm{~Pb} /{ }^{206} \mathrm{~Pb}$ ages of zircons from $\AA$ kerberg. (A) Indistinct wispy zoning (\# 8) and oscillatory zoned (\# 5) gabbro zircons, with ages indicating an approximate magmatic and metamorphic age, respectively; (B) Oscillatory (\# 2) and internal growth zoned (\# 9) zircons from the granodiorite, with ages indicating a magmatic emplacement age.

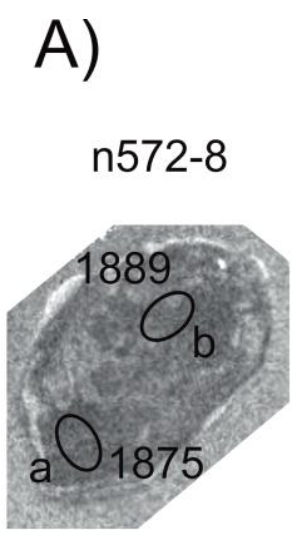

$\mathrm{Th} / \mathrm{U}=0.43(\mathrm{a})$ and $0.31(\mathrm{~b})$ n572-5

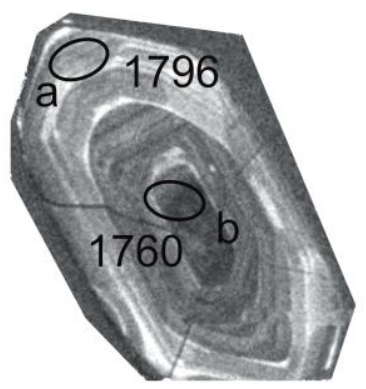

$\mathrm{Th} / \mathrm{U}=0.53(\mathrm{a})$ and $0.23(\mathrm{~b})$

\section{B)}

N1711-2

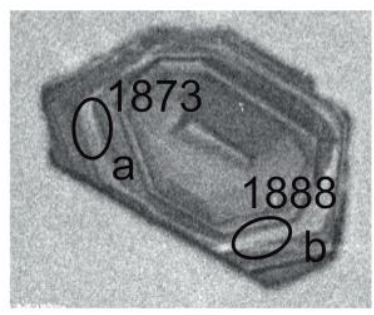

$\mathrm{Th} / \mathrm{U}=0.23(\mathrm{a})$ and $0.22(\mathrm{~b})$

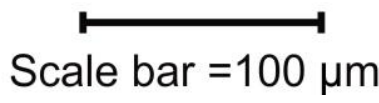

$\mathrm{n} 1711-9$



$\mathrm{Th} / \mathrm{U}=0.09$ (a) and 0.09 (b)

Two baddeleyite fractions from a gabbroic drill core (AKK 97) were analyzed using U-Pb TIMS. The fractions (black ellipses) largely overlap and plot 1.5\% discordant (inset in Figure 9; Table 2). The weighted mean of ${ }^{207} \mathrm{~Pb} /{ }^{206} \mathrm{~Pb}$ dates is $1878 \pm 2 \mathrm{Ma}$, and represents a robust minimum age of the sample.

Table 2. Baddeleyite U-Pb TIMS data.

\begin{tabular}{|c|c|c|c|c|c|c|c|c|c|c|c|c|}
\hline $\begin{array}{c}\text { Analysis number } \\
\text { (number of } \\
\text { grains) }\end{array}$ & U/Th & $\begin{array}{c}\text { Pbc/ } \\
\text { Pbtot }^{(1)}\end{array}$ & $\begin{array}{c}{ }^{206} \mathrm{~Pb} / \\
{ }^{204} \mathrm{~Pb} \\
\text { Raw }{ }^{(2)} \\
\end{array}$ & $\begin{array}{c}{ }^{207} \mathrm{~Pb} / \\
{ }^{235} \mathrm{U} \\
{[\text { corr }]^{(3)}}\end{array}$ & $\begin{array}{c} \pm 2 \mathrm{~s} \\
\mathrm{err} \%\end{array}$ & ${ }^{{ }^{206} \mathrm{~Pb} /}$ & $\begin{array}{l} \pm 2 \mathrm{~s} \\
\text { err\% }\end{array}$ & $\begin{array}{c}{ }^{207} \mathrm{~Pb} / \\
{ }^{235} \mathrm{U} \\
\text { [age, Ma] }\end{array}$ & $\begin{array}{c}{ }^{206} \mathrm{~Pb} / \\
{ }^{238} \mathrm{U}\end{array}$ & $\begin{array}{l}{ }^{207} \mathrm{~Pb} / \\
{ }^{206} \mathrm{~Pb}\end{array}$ & $\begin{array}{l} \pm 2 \mathrm{~s} \\
\text { err\% }\end{array}$ & Concord \\
\hline$\AA \mathrm{Ak}-\mathrm{c}$ & 104.7 & דe & 15554 & 5.2739 & 0.46 & 33306 & 0.45 & 1864.6 & 853.2 & 1877.4 & 2.0 & 0.987 \\
\hline Åk-1 (1 grain) & 103.7 & 0.011 & 5652 & 5.2547 & 0.50 & 0.33168 & 0.48 & 1861.5 & 1846.5 & 1878.3 & 2.1 & 0.983 \\
\hline
\end{tabular}

${ }^{(1)} \mathrm{Pbc}=$ common $\mathrm{Pb}$; Pbtot $=$ total $\mathrm{Pb}$ (radiogenic + blank + initial); ${ }^{(2)}$ measured ratio, corrected for fractionation and spike; ${ }^{(3)}$ isotopic ratios corrected for fractionation ( $0.1 \%$ per amu for $\mathrm{Pb}$ ), spike contribution, blank ( $1 \mathrm{pg} \mathrm{Pb}$ and $0.2 \mathrm{pg} \mathrm{U}$ ), and initial common $\mathrm{Pb}$. Initial common $\mathrm{Pb}$ corrected with isotopic compositions from the model of Stacey and Kramers (1975) at the age of the sample. 


\subsubsection{U-Pb Dating of the Granodiorite}

The SIMS study of the granodiorite (sample 94002) included 11 spots (Table 1; Figures 10b and 11). One grain (\# 12) turned out to be Archean in age $(2.65 \mathrm{Ga})$ and is characterized by an elevated $\mathrm{Th} / \mathrm{U}$ ratio well above 1.0. The remaining analyses suggest that a single, pre-1.8 Ga, age population dominates. Thus, in contrast to the gabbroic sample, there are no evident signs for any $1.8 \mathrm{Ga}$ metamorphic over-print and a calculated $\mathrm{U}-\mathrm{Pb}$ age would likely reflect a magmatic crystallization event. Five spots show a discordance of less than around 6\%, another spot (\# 9b) plots in a slightly inversely discordant position, and three additional spots display a larger discordance. One approach to deal with the discordant data is to carry out a linear regression of all spots and this leads to an age estimate of $1878 \pm 13 \mathrm{Ma}(\mathrm{MSWD}=3.6)$ and a lower intercept at $131 \pm 180 \mathrm{Ma}$. Alternatively, a calculated ${ }^{207} \mathrm{~Pb} /{ }^{206} \mathrm{~Pb}$ weighted average age using the five near-concordant spots (\# 1, 2a, 2b, 9a and 19) yields $1875 \pm 5 \mathrm{Ma}$. It may be noted that certain spots, with a similar degree of concordncy, show a scatter in their ${ }^{207} \mathrm{~Pb} /{ }^{206} \mathrm{~Pb}$ ages which is beyond the analytical uncertainty. This type of behavior could be indicating the presence of a minor inherited component. For instance, if an alternative regression is carried out which excludes data points 19 and $2 \mathrm{~b}$, both of which may indicate a certain inheritance, this yields an age of $1873 \pm 6 \mathrm{Ma}(\mathrm{MSWD}=1.5)$ which, however, still is consistent with the previously calculated 1875 Ma age.

Figure 11. U-Pb concordia diagrams with SIMS zircon data for the granodiorite; data with a pronounced discordance and indicating Archean ages are omitted.

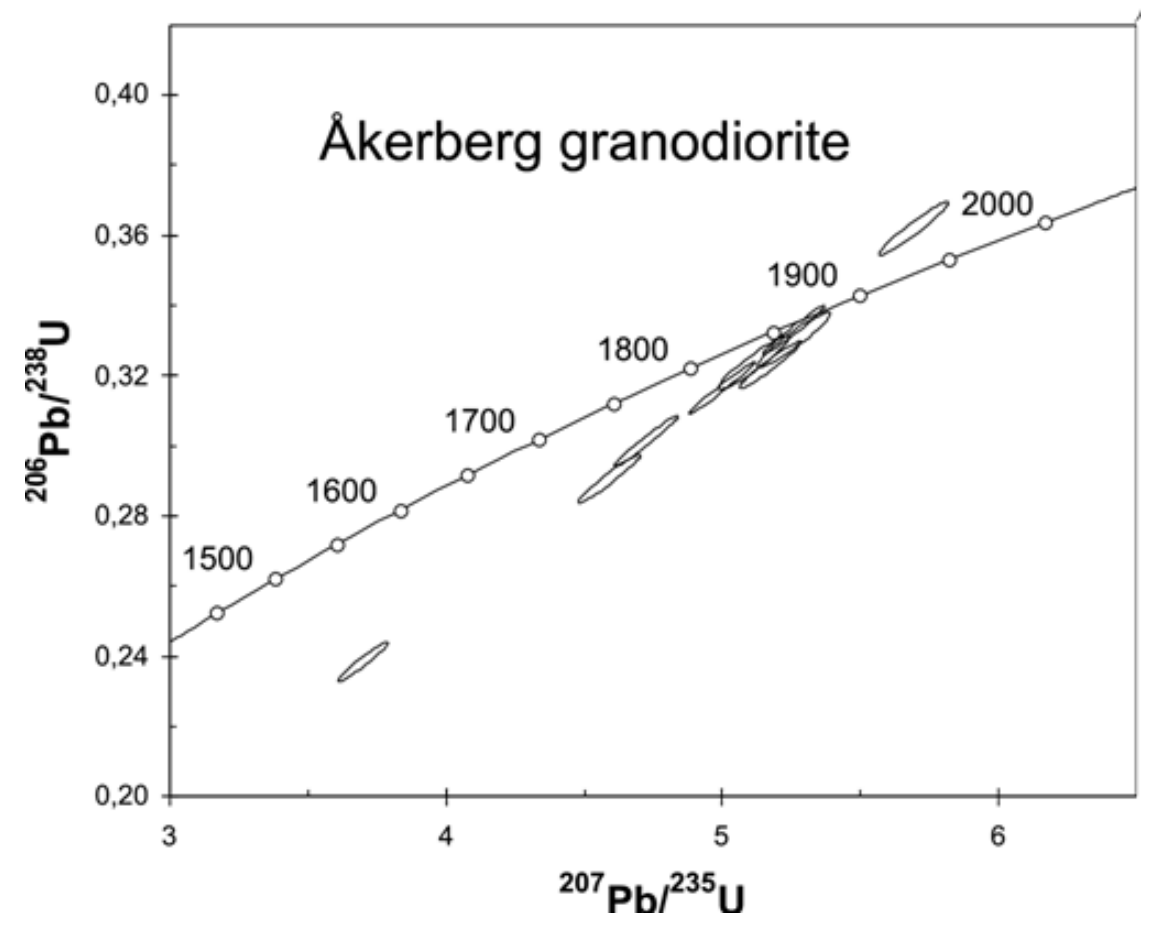

\subsubsection{Fluid Inclusion Results}

Surprisingly, the gabbro-hosted quartz veins contain no primary fluid inclusions. Only different types of 3-35 $\mu \mathrm{m}$ sized secondary aqueous and carbon dioxide-free inclusions, which outline healed 
microfractures that cross-cut the veins, occur. The inclusions are irregularly shaped, typically flat and comprise three types (Figure 12a-c).

Figure 12. Fluid inclusion homogenisation temperature (to liquid) plotted vs. salinity data for (a) the quartz vein hosted inclusions with a halite cube in addition to liquid and vapor; (b) the quartz vein hosted inclusions with liquid plus vapor or liquid-only inclusions $\left(=^{*}\right)$ and (c) the low-salinity $\mathrm{CO}_{2}$-bearing inclusions in the pegmatite. Decrepitation before homogenisation is indicated by the red stars.
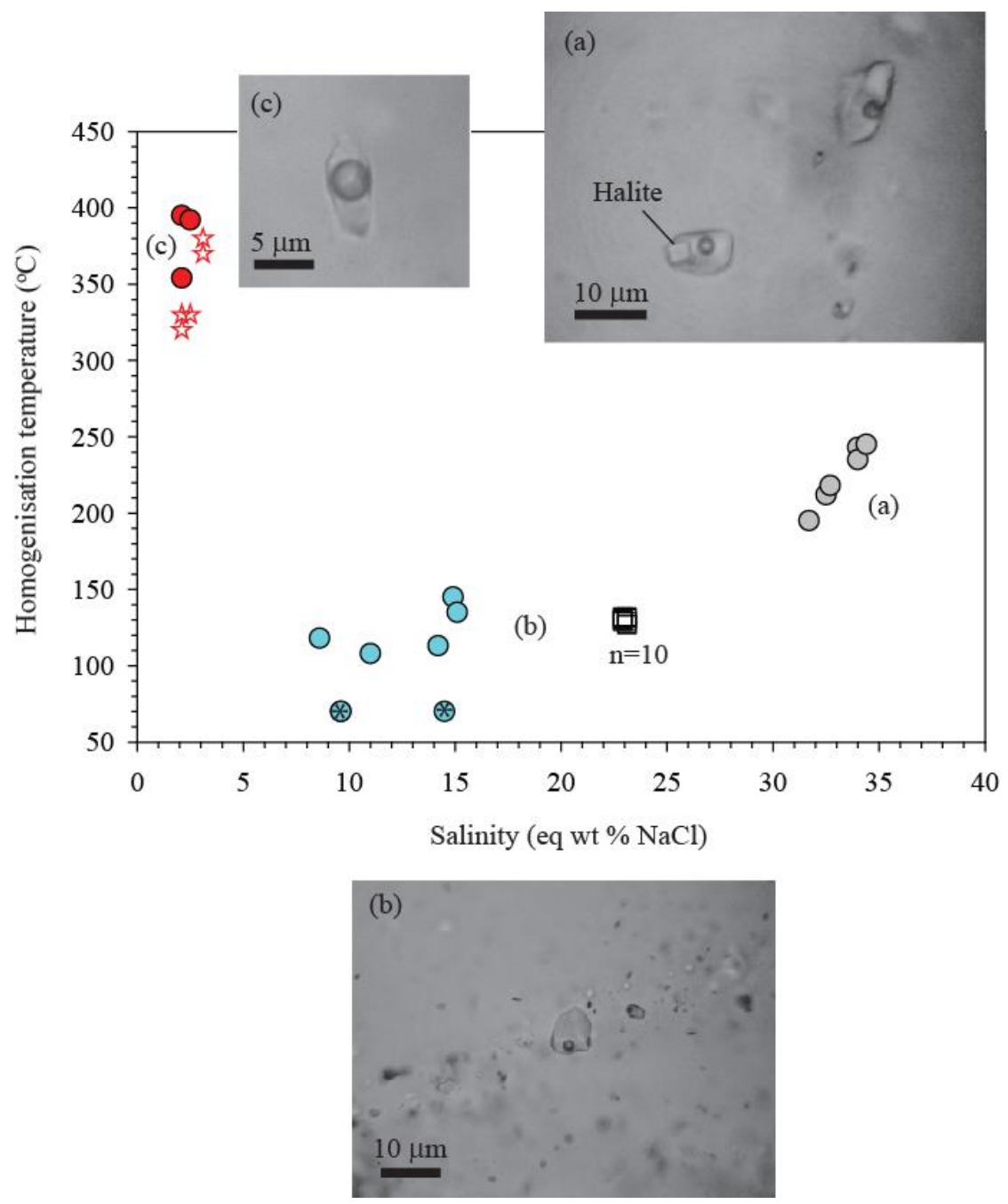

At room temperature these consist of (a) a single phase aqueous liquid, occasionally some of these contain a small vapor bubble (<1 vol \%); (b) two phases with a vapor bubble (2-5 vol \%) and an aqueous liquid; (c) three phases with a vapor (2-5 vol \%), an aqueous liquid and a halite cube $(\sim 5$ vol \%). The different types of secondary inclusions occur in separate microfractures. Microthermometric analyses show final ice melting temperatures, $\mathrm{T}_{\mathrm{m}}(\mathrm{ice})$, in the range $(\mathrm{a})-5.5{ }^{\circ} \mathrm{C}$ to $-11.1^{\circ} \mathrm{C}$ (for the single phase inclusions after an artificial vapor bubble has been generated by heating) and (b) $-20.8{ }^{\circ} \mathrm{C}$ to $-21.1{ }^{\circ} \mathrm{C}$. The halite in the third type (c) melts after heating to between $195{ }^{\circ} \mathrm{C}$ and $245^{\circ} \mathrm{C}$. For all three types initial melting was noted within the interval $-55^{\circ} \mathrm{C}$ to $-65^{\circ} \mathrm{C}$ which indicates a $\mathrm{CaCl}_{2}-\mathrm{NaCl}$ dominated fluid. Using the data in Bodnar [45] these temperatures correspond to gradual increasing salinities from (a) 8.6-15 wt \% NaCl, (b) 22.9-23.1 wt $\% \mathrm{NaCl}$ to (c) 31.6-34.4 wt $\% \mathrm{NaCl}$ 
equivalent. A similar trend was found for the homogenization temperatures, $T_{h}$ (to liquid in all cases). The lowest $T_{h}$ values were measured for (a) where those with a small vapor bubble have $T_{h}$ at $100-145^{\circ} \mathrm{C}$ (single phase inclusions give no $\mathrm{T}_{\mathrm{h}}$ ); (b) $127-132{ }^{\circ} \mathrm{C}$ and (c) where total homogenization were achieved by the halite melting at $195-245^{\circ} \mathrm{C}$.

The quartz vein sample from the granodiorite was devoid of fluid inclusions, but the quartz from the steeply dipping pegmatite contains both primary and secondary fluid inclusions. The primary type occurs at random in quartz grains with a more or less well-developed negative crystal shape. The inclusions consist of two phases with a large vapur bubble (20-30 vol \%) and an aqueous liquid. It was difficult to observe phase changes during cooling, but after employing a cooling-heating cycle procedure, gas-hydrates were formed around $-45^{\circ} \mathrm{C}$ and melting of the gashydrates could be observed around $+8.5^{\circ} \mathrm{C}$ to $+9{ }^{\circ} \mathrm{C}$. This implies the presence of low amounts ( $<2$ mole percent) of a dissolved gas phase in the aqueous phase and $\mathrm{CO}_{2}$ gashydrates dissolve at these temperatures in aqueous fluids with a salinity of 2-3 wt \% NaCl equivalent [46]. The inclusions homogenized to the liquid at $350{ }^{\circ} \mathrm{C}$ to $400{ }^{\circ} \mathrm{C}$. Secondary fluid inclusions in the pegmatite quartz were all single phase aqueous liquid inclusions. After an artificial vapor bubble has been generated in the inclusions by heating, initial ice melting was observed at $-25^{\circ} \mathrm{C}$ and final ice melting $\mathrm{Tm}$ (ice) was measured around $-0.5{ }^{\circ} \mathrm{C}$. The melting temperatures indicate a $\mathrm{NaCl}-\mathrm{KCl}$ dominated composition and a salinity of $0.9 \mathrm{wt} \% \mathrm{NaCl}$ equivalent [45].

\subsection{Discussion}

The timing of deformation and rock formation is crucial for unraveling the history of vein formation and gold deposition at Åkerberg. The critical span for gold-forming events in the Skellefte district and its neighborhood appears to be roughly constrained between 1.90 and $1.80 \mathrm{Ga}$ given the published information from different types of gold mineralizationin the region. Figure 8 summarizes the broad geological evolution of the Skellefte district and with respect to the regional tectonic history, the main introduction of gold was probably linked to either one of two stages; an early (1.88-1.86 Ga) event, and a subsequent $1.8 \mathrm{Ga}$ regional metamorphic event. Irrespective of the preferred temporal model for gold deposition, deformation and shearing structures most likely guided the localization of all significant gold mineralizations in the Skellefte district and its surroundings.

In a regional comparison, there are a number of unusual features observed in the Åkerberg deposit. Any suggested ore genetic model must attempt to accommodate the following features; (1) gold is not spatially associated with sulfides which comprise a very minor constituent in the ore. Although the gold grade is positively correlated with the density of quartz veins, which we take as an indication that gold deposition took place as part of the quartz vein-forming stage, gold is also found in between veins, as well as occurring at anomalous levels outside of veined areas in both the gabbro and in the granodiorite; (2) veins form a sheeted vein system suggesting that shearing, associated with a heterogeneous stress regime, was not a crucial factor during vein emplacement. The E-W trending veins in the ore zone are interpreted as extensional fractures; (3) alteration is very limited and is basically developed as an albitisation of feldspar; (4) no primary inclusions occur in the vein quartz which contains streaks of amphiboles. In our model, the key to interpret the deposition of gold is to understand the emplacement mechanisms and tectonic regime of the granodiorite magma and its hypothetical evolution which may include unmixing processes producing separate melts, vapor and aqueous fluids. 


\subsubsection{Ages of Rocks and Other Geological Constraints on Ore Formation at Åkerberg}

Sedimentary rocks constitute the oldest lithological unit in the Skellefte district and its surroundings, and the emplacement of such rocks has been suggested to span a long time interval between approximately 1.96 and $1.86 \mathrm{Ga}[47,48]$. The sedimentary rocks at Åkerberg overlie volcanic rocks which probably belong to the Skellefte Group, suggesting the former to be younger than approximately $1.89 \mathrm{Ga}[43,49,50]$. Taking into consideration also the observation that the 1.89-1.88 Ga gabbro contains clasts of sedimentary rocks, this suggests that the local gabbro, volcanic rocks and sediments must all have developed within a narrow $1.9-1.88 \mathrm{Ga}$ interval.

The exact age of the gabbro is not easily resolved given that $\mathrm{U}-\mathrm{Pb}$ data obtained from zircon and baddeleyite appear not to be fully consistent. Although ages almost overlap within errors, the former is seemingly 5-10 Ma older. Two hypotheses may explain the apparent age discrepancy; (1) the zircon age is too old or (2) zircon and baddeleyite ages date different events. First, it has been demonstrated that both TIMS; e.g., [49,50] and SIMS [43] U-Pb zircon data from elsewhere in the Skellefte district can suffer from problems with inheritance, resetting and discordance. This raises the possibility that the obtained $\mathrm{U}-\mathrm{Pb}$ zircon age is anomalously old due to inheritance, a feature which, however, is not clearly supported by CL imaging (Figure 10a). Second, it cannot be completely ruled out that the dioritic part of the gabbro, sampled for baddeleyite dating, actually crystallized slightly later than the gabbroic part (sampled for zircon). Baddeleyite $\mathrm{U}-\mathrm{Pb}$ results from two other layered gabbros, located within the northern part of the Jörn complex (Figure 1), yielded ages at $1879 \pm 1 \mathrm{Ma}$ and $1884 \pm 2 \mathrm{Ma}$, respectively [27]. This may indicate that mafic magmatism was not necessarily a very short-lived event in the region, and this hypothesis is consistent with the presence of mafic dykes intruding the gabbro at Åkerberg suggesting that the local mafic magmatism had a certain duration.

Another issue relates to the mode of baddeleyite formation. Baddeleyite is widely accepted to be a primary mineral in basaltic rocks (inheritance is not a factor), and although a baddeleyite age would normally be interpreted as reflecting the magmatic emplacement age, it should be recalled that unusually few baddeleyite grains were found. This could hypothetically mean that there is no magmatic population of baddeleyite present in the rock, and that either baddeleyite is of a hydrothermal origin as described from the Val DÒr gold deposit [51] or that the rare baddeleyite grains formed during a metamorphic process involving earlier formed zircon. The latter process means that a 1880 Ma metamorphic episode, associated with fluid infiltration and coupled release of Ca, caused $1890 \mathrm{Ma}$ zircons to break down and form baddeleyite in a manner similar to that described from the Ballachulish Igneous Complex (Scottish Highlands) [52]. The broadly similar ages for the baddeleyite and the granodiorite, and the strong influence of the gabbro induced by the latter magma as suggested in the presented ore genetic model, add some support to this hypothesis. Thus, although it is difficult to arrive to a definite answer as regards the age of the gabbro, it seems safe to conclude that the gabbro intruded during the 1.89-1.88 Ga interval. This is consistent with the observation that NE-SW shearing, tentatively representing a pre- $\sim 1.88 \mathrm{Ga}$ (D1) event, has affected the gabbro but not the 1875 Ma granodiorite. The observation that there are deformed sediment clasts in the 1.88 Ga gabbro may also be sign of a pre-1.88 Ga deformational event.

The granodiorite intrudes the gabbro and based on the chemistry and field appearance of the former, it can be assigned to a suite of granites referred to as Jörn GII type. This is supported by U-Pb zircon 
ion microprobe dating (Figure 11) yielding an $1875 \pm 5 \mathrm{Ma}$ age which is typical for a GII granitoid [26]. Apparently, the intrusion of the granodiorite followed closely upon the crystallization of the gabbro, during a stage which was characterized by intense magmatism and rapid uplift in the Skellefte district [24]. The single Archean grain (grain 12) reinforces that older detritus material may be assimilated during Svecofennian magma generation in the area near the Skellefte district $[43,53]$.

As suggested earlier, the exposed pegmatites define two discrete generations. Overall, pegmatites in the Svecofennian of Sweden are typically associated with volatile-rich, late-stage $1.8 \mathrm{Ga}$ S-type granites which formed during a regional metamorphic event. Exemplifying this point is the $1775 \pm 11 \mathrm{Ma}$ (U-Pb columbite) age of the complex LCT-type pegmatite at Varuträsk [34], located about $25 \mathrm{~km}$ south of Akerberg. Thus, it seems logical to anticipate a similar age for the complex, two-mica pegmatite at Åkerberg. However, we take the S-type affinity observed for the ore-associated $1875 \mathrm{Ma}$ old granodiorite as an indication that this rock was temporarily associated with the observed, early generation of pegmatites. Thus, there was probably a time gap of about one hundred million years between the crystallization of early, more steeply dipping, and late, complex pegmatite types. Parallel with the development of the complex pegmatite, major batholits of Skellefte- and Revsund-types were also emplaced, and an effect of such processes may be the development of gabbro-hosted $1.8 \mathrm{Ga}$ zircons of metamorphic origin.

\subsubsection{Field and Genetic Relationships between Rocks and Mechanisms for Quartz Veining}

Following the deposition of a sedimentary sequence, the gold-hosting gabbro is the oldest rock unit in the area. The development of the mylonite zones in this rock, which approximately outline the ore zone, is the first expression of the local deformation history. This ductile stage may have occurred more or less directly upon the solidification of the gabbro magma. Following this, and based on the observed field relationships between the granodiorite and the mineralized quartz veins in combination with age constraints, it is suggested that quartz veining and gold deposition took place at around $1875 \mathrm{Ma}$ ago in connection with the emplacement of the intrusive granodiorite and the steeply dipping pegmatite bodies.

To facilitate the discussion regarding the ore-forming conditions at Akerberg it is useful to reiterate a few general aspects of the formation of pegmatites. Pegmatites have traditionally been thought to have developed by equilibrium fractionation of coexisting granitic melt and hydrous fluid. However, for instance Thomas and co-workers [54] have proposed an alternative mechanism where a volatile-rich residual melt and fractionated granite magma may cross an immiscibility boundary and produce two very different melts. These melts have, for example, highly contrasting water content and viscosity, and using the terminology of Thomas and Webster [54] these may be referred to as a relatively water- and alkaline-poor (type A) and an extremely reactive, water- and alkaline-rich (type B) melt, respectively. Other phases, like an aqueous phase, may also result from immiscibility reactions and the formed melts and fluids will tend to physically separate from each other due to differences in chemical and physical parameters, and their original properties will change because of reactions with wall rocks. The least mobile (A) melt may form a normal quartz-feldspar pegmatite, whereas the highly reactive and mobile (B) melt may preferentially move into fractures in the wall rocks. With 
cooling the residual melt may become extremely enriched in volatile components, and incompatible elements like gold, get concentrated. A final melt phase may have the character of a silica gel.

We propose that the Akerberg granodiorite and the steep pegmatite with a simple mineralogy may have a common origin similar to the principal development outlined above. Supporting this is the observation that the large granodiorite intrusion occurs spatially associated with numerous small pegmatitic and granodioritic bodies (Figure 2). This proximity favors a genetic relation and gives the impression that felsic bodies do not just comprise the exposed intrusive units seen especially in the southern part of the gabbro, but are also underlying extensive parts of the gabbro. Assuming that this is correct, it is suggested that when intruding felsic magma bodies pushed from below on the shallow sheet-like gabbro, the latter ruptured and this induced a tight net-work of brittle, tensional cracks. This veining stage occurred at a shallower level, compared to the depth where the gabbro crystallized, as supported by the partly porphyritic appearance of the granodiorite. The ore zone is associated with the southern tip of the granodiorite and this setting may correspond to apical parts of an intruding granodiorite magma, and at such sites a large water phase may accumulate. A water-rich magma is an essential condition for triggering unmixing of a felsic magma and the related formation of a water-rich and a comparatively water-poor melt, respectively. If this scenario is applicable to the situation at Åkerberg, it follows that the moderately water-rich melt moved along zones of weakness and crystallized to granodiorite bodies of different size, whereas a reactive water-rich melt ultimately formed the pegmatite bodies and upon further fractionation a gel-like silicic component resulted. We suggest that a residual, gel-like melt got squeezed into a newly opened net-work of cracks in the gabbro and deposited barren quartz (silica). Also the emplacement of feldspar dikes in the gabbro was probably preceded by unmixing of melts. The described process of a melt invading and filling cracks in the gabbro show similarities with silicic segregations found in subvolcanic bodies in the northern Paraná Magmatic province [55].

\subsubsection{Factors Controlling Gold Transport, Ore-Associated Alteration and Distribution of Veins and Gold}

During magmatic differentiation by crystal fractionation, and a possible melt unmixing (yielding the granodiorite and the simple pegmatite) an immiscible (water-chloride) fluid phase may exsolve. Such a fluid may in turn separate into coexisting low-salinity aqueous vapor and hypersaline liquid (i.e., a brine) at the prevailing range of $P T$ conditions associated with magmatic intrusions in Earth's upper crust [56]. Generally, both a vapor phase and a brine phase scavenge gold from a melt phase, and several studies have acknowledged that vapor-transported gold may be transferred from a magma to porphyry and epithermal environments [56,57].

Since there is no fluid inclusion type that with certainty can be linked to gold deposition at Åkerberg, the detailed history of gold transport and depositional processes remains elusive. At least two hypotheses can be put forward; (1) gold and quartz (silica) were deposited together and (2) the gold depositing stage followed upon a stage of barren quartz formation. In favor of the first hypothesis are similarities with field evidence proposed to characterize certain mesothermal gold mineralizations [58]. Some of the textural features of mesothermal gold-quartz veins may be explained by the initial precipitation of amorphous silica gel (colloid), which subsequently crystallizes to quartz. This can occur in brittle-ductile shear zones in association with a significant pressure drop. The presence of 
colloidal silica can stabilize a gold colloid, allowing further transport of particulate gold in suspension in the hydrothermal fluid. Silica gel would tend to undergo rapid recrystallization to form quartz, whereas solid impurities would tend to be expelled toward grain boundaries. This model can account for the primary anhedral aggregate textures and the concentration of gold along grain boundaries occasionally observed at Åkerberg.

If, on the other hand, silica and gold deposition define two separate stages, it is possible that the secondary (saline) fluid inclusions found in microfractures in vein quartz are related to a stage of gold deposition which might have been synchronous with alteration along veinlet contacts. There is, however, no noted spatial connection between such inclusions and the presence of gold and if the observed secondary inclusions (implying a saline, $\mathrm{CO}_{2}$-free fluid) characterize the gold-bearing fluid, they are unusual with respect to typical gold-bearing fluids in epithermal and mesothermal environments. Further evidence supporting separate vein and gold-forming stages are presented in the ore genetic model.

As pointed out before, alteration is very limited at the Åkerberg gold deposit. We believe that this has to do with the suggested non-hydrothermal emplacement mode of vein quartz. Hence, the water: Rock ratio in the ore-forming system was low and there was probably no significant input of cool meteoric fluids governing ore-related alteration. Besides, the anticipated minor temperature contrast between the magmatic vapor/fluid that tentatively transported gold and the gabbroic host-rock, which remained relatively hot upon its emplacement due to the effect of intruding felsic and mafic magmas, did not promote alteration processes. The observed alteration features can be seen as reaction products between a minor magmatic-hydrothermal fluid phase and the gabbro. For instance, albitisation of feldspar at Åkerberg is consistent with an addition of sodium from the inferred residual melt, or related fluids, which transformed calcic plagioclase in the gabbro. Most likely, also tungsten being a granitophile element and which occurs as scheelite in the ore was sourced from this felsic melt. Ilmenite, which is another alteration phase probably formed when titanium was liberated from the gabbro.

The type of sulfides present and the orientation of vein systems warrant some further consideration. Sulfides occur in layers here and there in the gabbro, and it is possible that the rare vein sulfides at least partly were remobilized from pre-existing sulfides, reinforcing the sulfur-poor nature of ore fluids. Moreover, the type of sulfides found associated with quartz veins is distinct at different sites and this may have bearing on the vein-forming history. The dominant type of mineralized quartz veins, which for instance makes up the mined ore body, often trend E-W or NW-SE and carries minor amounts of pyrrhotite \pm pyrite. This is different from the characteristics of the wider N-S trending arsenopyrite-bearing veins that occur not only in the gabbro but also in the surrounding sedimentary rocks. Arsenopyrite-bearing and gold-associated quartz veins are also important at other localities near the Skellefte district (e.g., at Fäboliden, Svartliden, Grundfors and Skäggträskberget; see earlier stated references), where sedimentary rocks predominate, and have been interpreted to be part of the $1.8 \mathrm{Ga}$ metamorphic history [16,18]. These circumstances add some support to the view that quartz veins actually may have formed at different times at Åkerberg and could represent two generations, one early dominant system expressed by E-W veins forming the Au-rich zone, followed by a younger $(1.8 \mathrm{Ga}) \mathrm{N}-\mathrm{S}$ arsenopyrite-bearing vein system into which gold, to some minor extent, was mobilized from earlier existing sites. 


\subsubsection{Classifying the Åkerberg Gold Deposit: An Intrusion-Related Type of Mineralization}

It is not possible to find any counterparts to the Åkerberg deposit in northern Sweden and we are neither aware of any similar occurrence elsewhere in the Fennoscandian shield. A similar style of mineralization as found at Åkerberg (parallel and continuous thin veins, minor alteration and very low sulfide content, large gold-anomalous areas and gold distributed also between quartz veins, basically only gold and minor tungsten with, e.g., no tellurium or bismuth minerals present) appears to be quite rare also in a global perspective (Table 3). Although, certain intrusive-related quartz vein deposits in Korea [59] show several similarities with the Akerberg deposit, even better analogues are the intrusion-related Mokrsko deposit in Bohemia and deposits in the Tombstone gold belt in Yukon. At Mokrsko, tightly spaced (less than $1 \mathrm{~mm}$ wide) and parallel quartz veinlets formed during an E-W compression [60,61]. These steeply dipping veinlets occur in a granodiorite and surrounding volcano-sedimentary rocks. Besides, the sulfide (pyrite, arsenopyrite and pyrrhotite) content is low, generally less than $1 \%$, and the alteration is very minor. Another similarity between the Akerberg and Mokrsko deposits is their tentative emplacement within an actively deforming collisional environment. The Tombstone Gold Belt is a type area for the intrusion-related gold system mineral deposit model, and key features of this deposit type are discussed by, e.g., [21,62-64]. As an example, gold at Dublin Gulch is hosted by sheeted quartz vein arrays, 3-5 veins per meter, which are sparse in iron sulfides [62].

Several authors have attempted to define features that can help discriminate between intrusion-related and orogenic type of gold deposits. Groves et al. [65] suggested that the presence of $\mathrm{W}-\mathrm{Sn}$ deposits in the magmatic province and a continental tectonic setting well inboard of convergent plate boundaries as diagnostic for intrusion-related type of deposits. There are no W-Sn deposits in the Åkerberg area, although such mineralizations occur in the so called "Au line" west of the Skellefte district where some potential intrusion-related deposits occur [14,24]. However, Åkerberg is tentatively situated in a back-arc region [34] which appears to be consistent with a typical tectonic setting for the intrusion-related group of deposits. Similarly, the described features at Akerberg are also reconcilable with the discriminators suggested by Hart \& Goldfarb [21] for intrusion-related gold deposits; namely (1) regional location in deformed shelf sequences on the inboard side of a series of accreted terranes and within terranes that also contain important tin and (or) tungsten deposits; (2) local spatial association of gold ores with cupolas and contact aureoles of relatively reduced, alkaline-leaning, and volatile-rich plutons; (3) post-deformational timing of gold deposition; (4) extremely low sulfide content (commonly <1 vol \%) of ores within igneous bodies and the outward zoning, through proximal skarns and to distal base metal-rich veins, from the causative pluton; and (5) low grades $(<1 \mathrm{~g} / \mathrm{t} \mathrm{Au})$ of auriferous sheeted vein systems in pluton cupolas. Hence, with respect to the overall features recognized for typical intrusion-related deposits, the Åkerberg gold occurrence provides a good example of such a type. In contrast, other gold deposits in the Skellefte district region, such as, e.g., Grundfors [16], may exemplify an orogenic type of gold deposit, which is widely held to result from crustal-scale flow in connection with metamorphic dehydration [20]. 
Table 3. Essential features of the Åkerberg gold deposit and a comparison with epigenetic gold deposits elsewhere.

\begin{tabular}{|c|c|c|c|c|c|c|c|}
\hline Deposit & Location & Geological setting & Host rock and ore setting & Ore & Vein mineralogy & Alteration & References \\
\hline \multicolumn{8}{|c|}{$\begin{array}{r}\text { Intrusion-hosted examples (continental margin setting - behind arcs), spatially related to felsic granitoids showing porphyry textures and associated with aplites/pegmatites, carbonic fluids, sheeted } \\
\text { vein-style, minor alteration, elevated } \mathrm{Bi}, \mathrm{W}, \mathrm{As} \text { and } \mathrm{Te}, \text { coeval with plutonism) }\end{array}$} \\
\hline Åkerberg & $\begin{array}{l}\text { East of } \\
\text { SOD }\end{array}$ & $\begin{array}{l}\text { Gabbro-granite complex, } \\
\text { at border } \\
\text { back-arc/marine basin }\end{array}$ & $\begin{array}{l}\text { Gabbro, ore at the tip of an } \\
\text { elongate granite intrusion }\end{array}$ & $\begin{array}{l}\text { Sheeted, thin parallell } \\
\mathrm{qz}^{2} \text { veins, dense spacing }\end{array}$ & $\begin{array}{c}\mathrm{Qz}+\text { very minor sulfides (py } \\
{ }^{3}, \text { po }^{4}, \text { rare } \mathrm{sp}^{7} \text { and } \\
\text { cpy }^{5} \text { ), minor W }\end{array}$ & $\begin{array}{l}\text { Very minor } \\
\text { (albitisation) }\end{array}$ & This study \\
\hline Björkdal & $\begin{array}{l}14 \text { km SSW } \\
\text { of Åkerberg }\end{array}$ & $\begin{array}{c}\text { Felsic intrusion, } \\
\text { volc-sedimentary rocks at } \\
\text { border } \\
\text { back- arc/marine basin }\end{array}$ & $\begin{array}{c}\text { Contact between granodiorite } \\
\text { and marble }\end{array}$ & $\begin{array}{l}\text { Decimetre-metre veins in } \\
\text { radial pattern }\end{array}$ & $\begin{array}{l}\text { Qz, minor amounts of sulfides } \\
\left(\text { cpy }^{5}, \text { py }^{3},\right. \\
\left.\text { po }^{4}\right), \text { sch }^{8} \text {, tour }{ }^{9}, \text { cc }^{10} \text { and } \\
\text { Sb-Bi phases }\end{array}$ & $\begin{array}{l}\text { Minor (act, sericite, } \\
\text { biotite) }\end{array}$ & [5-7] \\
\hline Mokskro & Bohemia & $\begin{array}{l}\text { Folded and } \\
\text { metamor-phosed Jilové } \\
\text { sequence }\end{array}$ & $\begin{array}{c}\text { Contact between granodiorite } \\
\text { apophysis and } \\
\text { volc-sedimentary rocks }\end{array}$ & $\begin{array}{c}\text { Parallel, thin sheeted } \mathrm{qz}^{2} \\
\text { veinlets in } \\
\text { granodiorite-hosted ore }\end{array}$ & $\begin{array}{l}\text { Qz and minor sulfides } \\
\left(\text { mainly apy }{ }^{6}\right) ; \mathrm{Bi}-\mathrm{Te}\end{array}$ & $\begin{array}{c}\text { Very minor } \\
\text { (microcline and } \\
\text { recrystallised } \\
\text { amphibole and biotite) }\end{array}$ & [60] \\
\hline $\begin{array}{l}\text { Dublin } \\
\text { Gulch }\end{array}$ & $\begin{array}{l}\text { Yukon } \\
\text { territory }\end{array}$ & Miogeoclinal & $\begin{array}{l}\text { Granodiorite stock within } \\
\text { meta-sediments }\end{array}$ & $\begin{array}{c}\text { Sheeted quartz veins, vein } \\
\text { density may exceed } 20 \\
\text { veins } / \mathrm{m}\end{array}$ & $\begin{array}{l}\text { Minor sulfides, scheelite, Bi- } \\
\text { minerals }\end{array}$ & $\begin{array}{l}\text { Moderate (K-fsp, } \\
\text { minor albite, some } \\
\text { sericite-carbonate) }\end{array}$ & [62] \\
\hline
\end{tabular}

IOCG type examples (arc or fore-arc setting, mainly hosted by sedimentary and volcanic rocks, carbonic fluids, antithetic tensional vein arrays, minor-moderate alteration, timing is syn-regional metamorphism)

\begin{tabular}{|c|c|c|c|c|c|c|c|}
\hline Fäboliden & $\mathrm{W}$ of SOD & $\begin{array}{l}\text { Supracrustals at border } \\
\text { fore-arc/marine basin }\end{array}$ & Mainly a greywacke & $\begin{array}{c}\text { Sheared } \mathrm{qz}^{2} \text { veinlets, } \\
\text { alteration zones }\end{array}$ & $\begin{array}{l}\mathrm{Qz}+\text { moderate amounts of } \\
\text { apy }^{6}, \text { po }^{4}, \text { loell } \\
\end{array}$ & $\begin{array}{l}\text { Significant (mainly K- } \\
\text { fsp, diopside, } \\
\text { amp }^{12} \text {, biotite, } \mathrm{qz}^{2} \text { ) }\end{array}$ & [18] \\
\hline
\end{tabular}

${ }^{(1)} \mathrm{SOD}=$ Skellefte ore district; ${ }^{(2)} \mathrm{qz}=\mathrm{quartz} ;{ }^{(3)} \mathrm{py}=$ pyrite; ${ }^{(4)} \mathrm{po}=$ pyrrothite; ${ }^{(5)} \mathrm{cpy}=$ chalcopoyrite; ${ }^{\left({ }^{6}\right)}$ apy=arsenopyrite; ${ }^{(7)} \mathrm{sp}=\mathrm{sphalerite} ;{ }^{\left({ }^{(8)}\right.}$ sch=scheelite; ${ }^{(9)}$ tour=tourmaline; ${ }^{(10)}$ cc=calcite;

${ }^{(11)}$ loell=loellingite; ${ }^{(12)}$ amp $=$ amphibole. 


\section{Experimental Section}

We have adopted radiometric dating as well as fluid inclusion techniques. The radiometric study involved in situ (SIMS) U-Pb isotope analyses of zircons separated from the gabbro and from the granodiorite at Åkerberg. Moreover, the gabbro was also conventionally dated by means of baddeleyite $\mathrm{U}-\mathrm{Pb}$ analysis. Prior to the masspectrometrical analysis, zircon grains were subjected to cathodoluminescence (CL) imaging.

\subsection{Sample Descriptions and Analytical Techniques}

The gabbro sampled for zircon dating (referred to as sample 96016) was taken from blasted material approximately $300 \mathrm{~m} \mathrm{NW}$ from the mine (coordinates N722490/E173215; Figure 2). Zircons from this rock are few, light-brown and around $100 \mu \mathrm{m}$ in size. Grains are sub- to euhedral and both transparent and turbid varieties occur (Figure 10A). Three of the analyzed grains display oscillatory zoning (Figure 10A) and a few others comprise inner structures that may be interpreted as cores. Moreover, a blurry zoning is present in several of the grains (Figure 10A), and altogether zircons display a fairly heterogeneous character. Zircons from the granodiorite (sample 94002; located some one hundred meter north of 96016) are mainly sub- to anhedral, often with rounded edges, although more prismatic types also occur (Figure 10B). Most of the grains are metamict with plenty of cracks, and occasionally few inclusions occur. Zircons may show various internal CL patterns such as oscillatory zoning, sector zoning and probable dissolution-recrystallization features (Figure 10B). The U-Pb single-grain zircon data were acquired by SIMS (Secondary Ion Mass Spectrometry) technique using an ion microprobe (the NORDSIM facility) at the Laboratory of Isotope Geology (LIG) at the Swedish Museum of Natural History in Stockholm. The polished zircon mounts were coated with a $30 \mathrm{~nm}$ layer of gold. Analytical procedures and common lead corrections are similar to those described by Whitehouse et al. [66]. A primary $\mathrm{O}_{2}{ }^{-}$ion beam was focused into a spot with a diameter of 20-25 $\mu \mathrm{m}$ that sputters material from the sample to leave a flat-bottomed crater. Positive ions sputtered from the crater are extracted and mass-separated into the peaks of interest: ${ }^{90} \mathrm{Zr}_{2}{ }^{16} \mathrm{O},{ }^{204} \mathrm{~Pb},{ }^{206} \mathrm{~Pb},{ }^{207} \mathrm{~Pb},{ }^{208} \mathrm{~Pb},{ }^{238} \mathrm{U},{ }^{232} \mathrm{Th}{ }^{16} \mathrm{O}$, and ${ }^{238} \mathrm{U}^{16} \mathrm{O}$. Calibrations of $\mathrm{Pb} / \mathrm{U}$ ratios are based on the observed relationship between $\mathrm{Pb} / \mathrm{U}$ and $\mathrm{UO}_{2} / \mathrm{U}$. Typically, several spots were analyzed in grains where different growth zones were suspected on the basis of CL images. Common lead corrections were done according to Stacey \& Kramers [67] using the apparent ${ }^{207} \mathrm{~Pb} /{ }^{206} \mathrm{~Pb}$ age. Weighted average ${ }^{207} \mathrm{~Pb} /{ }^{206} \mathrm{~Pb}$ ages were calculated using ISOPLOT [68]. Tabulated errors on ratios and ages are 1 sigma, and include propagated errors on the standard (Geostandards 91500; 1065 Ma, Wiedebeck et al. [69] analyses. All results of regression calculations are presented at the $95 \%$ confidence level.

Conventional U-Pb TIMS work has been applied on baddeleyite separated from another gabbro locality (AKK 97; 111.55-112.90 m) situated about $50 \mathrm{~m}$ east of the previously discussed gabbroic rock. Approximately $1 \mathrm{~kg}$ of a drill core characterized by a more dioritic composition was processed for high-density minerals for U-Pb geochronology, and separated using the procedures described by Söderlund and Johansson [70]. The yield of baddeleyite was exceptionally poor and only some tens of grains were recovered. The baddeleyite grains are fresh and dark brown to almost black. Dissolution, ion exchange chromatography and mass spectrometry were performed at LIG. The baddeleyite grains were transferred to mini teflon capsules and washed in 2-3 $\mathrm{M} \mathrm{HNO}_{3}$ on hot plate for $\sim 10$ min, washed 
successively in ultra-clean $\mathrm{H}_{2} \mathrm{O}$ before adding a small amount of ${ }^{205} \mathrm{~Pb}^{235-236} \mathrm{U}$ isotopic tracer solution and 10 drops of a $\mathrm{HF}-\mathrm{HNO}_{3}$ mixture (in proportions 10:1). The baddeleyite grains were completely dissolved over night at $210{ }^{\circ} \mathrm{C}$. After evaporation on hot plate the sample was dissolved in $3.1 \mathrm{M} \mathrm{HCl}$ and loaded on $50 \mu \mathrm{L}$ columns with anion exchange resin. After washing by $3.1 \mathrm{M} \mathrm{HCl}$, the uranium and lead were eluted by $\mathrm{H}_{2} \mathrm{O}$ and dried down on hot plate. The $\mathrm{U}$ and $\mathrm{Pb}$ were loaded on the same single Re filament with $2 \mu \mathrm{L}$ silica gel. Mass spectrometry analysis was performed on a Finnigan MAT $261 .{ }^{208} \mathrm{~Pb},{ }^{207} \mathrm{~Pb}$ and ${ }^{206} \mathrm{~Pb}$ were measured using Faraday collectors. The ${ }^{207} \mathrm{~Pb} /{ }^{204} \mathrm{~Pb}$, used for common lead correction, was measured in dynamic collector mode using a Secondary Electron Multiplier. After completed $\mathrm{Pb}$ isotopic measurements (in the $1200-1320{ }^{\circ} \mathrm{C}$ range) the $\mathrm{U}$ isotopic composition was analyzed in dynamic multicollector mode at a filament temperature of $\geq 1350{ }^{\circ} \mathrm{C}$. Procedural blank is estimated to $1 \mathrm{pg} \mathrm{Pb}$ and $0.2 \mathrm{pg} \mathrm{U}$. Mass fractionation is $0.1 \%$ per mass unit for $\mathrm{Pb}$, determined by replicate analyses of NBS standards SRM 981 and SRM 983. U fractionation was determined directly from the measured ${ }^{233} \mathrm{U} /{ }^{236} \mathrm{U}$ isotopic ratio. Initial $\mathrm{Pb}$ compositions were taken from the model of Stacey and Kramers [67] at the age of the sample, and the decay constants used are those from Jaffey et al. [71]. The listed uncertainties in $\mathrm{Pb} / \mathrm{U}$ ratios (Table 1) were calculated by propagating the within-run error for measured isotopic ratios, and the uncertainties in fractionation ( \pm 0.04 for $\mathrm{Pb}$, absolute uncertainties), in $\mathrm{Pb}$ and $\mathrm{U}$ blank concentration $( \pm 50 \%)$, and in the $\mathrm{Pb}$ blank composition $\left(2 \%\right.$ for ${ }^{206} \mathrm{~Pb} /{ }^{204} \mathrm{~Pb}$ and $0.2 \%$ for $\left.{ }^{207} \mathrm{~Pb} /{ }^{204} \mathrm{~Pb}\right)$.

A reconnaissance study of fluid inclusions has also been made on three hand specimens of quartz veins from the mineralized gabbro and, for a comparison, one sample each from a quartz vein in the associated metagranodiorite and quartz from a steeply dipping pegmatite were included. Fluid inclusions in $150 \mu \mathrm{m}$ thick doubly polished sections were then studied at the Department of Geological Sciences, Stockholm University by microthermometry. A conventional microscope was used to get an outlook of the samples and the distribution of fluid inclusions. Microthermometric analyses were carried out in the temperature range $-196{ }^{\circ} \mathrm{C}$ to $600{ }^{\circ} \mathrm{C}$ on a Linkam THM 600 heating and cooling stage. The reproducibility is $\pm 0.1{ }^{\circ} \mathrm{C}$ for temperatures below $+40{ }^{\circ} \mathrm{C}$ and $\pm 0.5{ }^{\circ} \mathrm{C}$ for temperatures above $+40^{\circ} \mathrm{C}$. The stage was calibrated with synthetic fluid inclusion standards (SynFlinc).

\section{Conclusion: A Genetic Model for the Åkerberg Gold Deposit}

The Åkerberg gold ore is hosted by a layered gabbro and the developed sheeted vein complex argues for a formation in dilatational zones in the competent, gabbroic rock. The veins form en echelon fracture/vein arrays which normally are ascribed to extensional fracturing [72]. Veining took place subsequent to a mylonitization event (D1) when the voluminuous granodioritic melt intruded and buckled the gabbro, and this occurred during a period of extension and uplift, which coincides in time with the deposition of the 1.88-1.87 Ga Vargfors and Arvidsjaur Groups further to the west and north [1]. The intruding granodiorite magma caused the gabbro sheet to rupture, and upon unmixing of the magma, a silica-rich gel got squeezed itself into newly opened tensional cracks in the gabbro. It should be pointed out that the presence of a quartz melt is not anticipated in the suggested ore model. Such an interpretation, which would assume unrealistically high temperatures, can be rejected giving the lack of alteration connected with quartz veining. The lack of primary fluid inclusions in the gabbro-hosted quartz veins favors vein formation from a gel-like melt rather than being caused by 
hydrofracturing. In connection with the invading felsic melts, gabbro-hosted fragments of amphiboles, which got ripped off during fracturing, became assimilated by the gel. The presence of a viscous silica gel is further consistent with the observation that the amphiboles are aligned and form parallel schlieren, mimicking that of flow textures within quartz veins.

The exact timing of gold deposition and the mode of gold transport can not be easily constrained. For instance, it cannot be ruled out that a gold-rich melt was mobilized into fracture zones in the gabbro similar to the case described in the Challenger gold deposit, south Australia [73], where a polymetallic melt was mobilized into leucosomes in a pelitic host rock. However, the observation that gold occurs not only closely associated with quartz veins but also in areas between veins and outside vein-bearing zones suggest that quartz formation and gold introduction are separate processes. This appears to be supported by scheelite, which is a mineral that closely follows gold and that partly occurs randomly in the gabbro. Therefore, it may be assumed that gold deposition followed an initial stage of barren quartz vein formation. Probably, gold along with, e.g., scheelite, and minor alteration phases were precipitated from an ore fluid which ultimately was derived from the granodioritic magma. However, if this gold-bearing fluid was exsolved directly from the magma, or if it formed from a gold-bearing magmatic vapour phase remains an open question. Given the low sulfide content, and the likeliness that at least some of the vein sulfides are primary constituents of the gabbro, it is possible that not only sulfur-complexing but also, e.g., OH-complexing may have been important for gold transport. A good candidate for the source of gold may be the granodiorite itself. This rock which occasionally shows a porphyritic texture is, petrologically and age-wise, similar to gold-related porphyries elsewhere in the Skellefte district, as exemplified by those at Älgträsk [11], Vinliden and Storklinten [8], and a genetic connection between porphyry magmatism and gold formation seems likely.

The mined ore body comprises a system with E-W veins having economic grades of gold which was developed near the southern tip of a large granodioritic body, but gold is also erratically distributed in other fractured parts of the gabbro (and in the granodiorite). This distribution is probably controlled by the local geometry and related deformational directions between intruding granodioritic magma bodies and the gabbro sheet, which resulted in both E-W and NW-SE oriented veins. Some quartz veinlets are also found within the granodiorite and the formation of gold-bearing quartz veinlets possibly occurred over a period of time, which would explain why the granodiorite either is cross-cutting quartz veins or is being cut by them. It is also suggested that two generations of quartz vein systems exist at Åkerberg. Strengthening this interpretation is the fact that the inferred young (arsenopyrite-bearing) vein system follows the same direction as the regionally developed late-stage (D3), N-S shear systems which affect not only all the country rocks, including pegmatites spatially associated with $1.8 \mathrm{Ga}$ granites, but also the E-W trending ore zone. Basically, the ore zone has escaped much of post-vein deformation given the observation that quartz veins basically follow a straight, parallel manner. Minor shearing of the E-W vein systems is probably due to late-stage deformation. It is also likely that a locally seen widening of the ore zone may be due to a repetition induced by late-stage shearing.

\section{Acknowledgements}

Discussions and help during field work with colleagues at the Boliden Mineral AB are greatly appreciated. Ingmar Lundström has kindly critically read the manuscript. We thank journal reviewers 
for invaluable comments that helped to significantly improve this paper. US acknowledges a grant from the Swedish Research Council. Martin Whitehouse and Kerstin Lindén are thanked for their assistance at the NORDSIM facility. The NORDSIM facility is operated under an agreement between the research funding agencies of Denmark, Norway, Iceland and Sweden, and the Geological Survey of Finland and the Swedish Museum of Natural History. This is NORDSIM contribution 330.

\section{References}

1. Allen, R.L.; Weihed, P.; Svensson, S.-A. Setting of Zn-Cu-Au-Ag sulfide deposits in the evolution and facies architecture of a $1.9 \mathrm{Ga}$ marine volcanic arc, Skellefte district, Sweden. Econ. Geol. 1996, 91, 1022-1053.

2. Nicolson, D.; Rickard, D.; Jonsson, R. Gold distribution in volcanogenic massive sulfide ores, Skellefte district, N. Sweden. Geol. Soc. Aust. Abstr. Ser. 1988, 23, 161-164.

3. Weihed, J.B.; Bergström, U.; Billström, K.; Weihed, P. Geology, tectonic setting and origin of the Paleoproterozoic Boliden $\mathrm{Cu}-\mathrm{Au}-\mathrm{As}$ deposit, Skellefte district, northern Sweden. Econ. Geol. 1996, 91, 1073-1097.

4. Gáal, G.; Gorbatschev, R. An outline of the Precambrian evolution of the Baltic shield. Precambrian Res. 1987, 35, 15-52.

5. Broman, C.; Billström, K.; Gustavsson, K.; Fallick, A.E. Fluid inclusions, stable isotopes and gold deposition at Björkdal, northern Sweden. Miner. Deposita 1994, 29, 139-149.

6. Weihed, P.; Weihed, J.B.; Sorjonen-Ward, P. Structural evolution of the Björkdal gold deposit, Skellefte district, northern Sweden: Implications for early Proterozoic mesothermal gold in the late stage of the Svecokarelian orogen. Econ. Geol. 2003, 98, 1291-1310.

7. Billström, K.; Broman, C.; Jonsson, E.; Recio, R.; Boyce, A.J.; Torssander, P. Geochronological, stable isotopes and fluid inclusion constraints for a premetamorphic development of the intrusive-hosted Björkdal Au deposit, northern Sweden. Int. J. Earth Sci. 2009, 98, 1027-1052.

8. Weihed, P.; Bergström, U. Proterozoic gold mineralizations in the Skellefte district, northern Sweden. In Proceeding of International Symposium Bicentennial Gold '88, Melbourne, Australia, 16-20 May 1988.

9. Bergström, U.; Weihed, P. Structural aspects of some gold mineralizations in the Skellefte district. Geol. Fören. Stockh. Förh. 1991, 113, 42-44.

10. Weihed, P. Litogeochemistry, metal and alteration zoning in the Proterozoic Tallberg porphyry-type deposit, northern Sweden. J. Geochem. Explor. 1992, 42, 301-325.

11. Bejgarn, T.; Årebäck, H.; Weihed, P.; Nylander, J. Geology, petrology and alteration geochemistry of the Palaeoproterozoic intrusive hosted Älgträsk Au deposit, northern Sweden. Geol. Soc. Lond. 2011, 350, 105-132.

12. Broman, C.; Bergström, U.; Lindblom, S. Fluid evolution in gold-bearing veins associated with feldspar porphyry dikes at Vinliden in the Skellefte District, northern Sweden. Geol. Fören. Stockh. Förh. 1995, 117, 233-244.

13. Bergström, U. Gold mineralization in the Vinliden area, Skellefte District, northern Sweden. Geol. Fören. Stockh. Förh. 1996, 118, A43-A44. 
14. Sundblad, K.; Weihed, P.; Billström, K.; Markkula, H.; Mäkelä, M. Source of metals and age constraints for epigenetic gold deposits in the Skellefte and Pohjanmaa districts, central part of the Fennoscandian Shield. Miner. Deposita 1993, 28, 181-190.

15. Bergman, J.; Bergström, U.; Weihed, P. Genesis and structural evolution of early Proterozoic gold lode deposits in the Skellefte district, northern Sweden. In Proceedings of the 28th International Geological Congress, Washington, DC, USA, 9-19 July 1989.

16. Bergman, J. Structural geology of Grundfors, a quartz vein related gold deposit in the Skellefte district, northern Sweden. Geol. Fören. Stockh. Förh. 1992, 114, 227-234.

17. Hart, I.; Marsh, S.; Laurent, I. Svartliden-A new style of mineralization in the Skellefte district In Gold '99 Trondheim: Precambrian Gold in Fennoscandian and Ukrainian Shields and Related Areas: Abstract Volume, Proceeding of Nordic Mineral resources Symposium, Trondheim, Norway, 4-6 May 1999; Cook, N.J., Sundblad, K., Eds.; Geological Survey of Norway: Trondheim, Norway, 1999; pp. 87-88.

18. Bark, G.; Weihed, P. Orogenic gold in the new Lycksele-Storuman ore province, northern Sweden: The Palaeproterozoic Fäboliden deposit. Ore Geol. Rev. 2007, 32, 431-451.

19. Robert, F.; Poulsen, K.H.; Dubé, B. Gold deposits and their geological classification. In Geophysics and Geochemistry at the Millennium: Proceedings of Exploration 97: Fourth Decennial International Conference on Mineral Exploration, Proceeding of Fourth Decennial International Conference on Mineral Exploration, Toronto, Canada, 14-18 September 1997; Gubins, A.G., Ed.; Prospectors and Developers Association of Canada: Toront, ON, Canada, 1997; pp. 209-220.

20. Groves, D.I.; Goldfarb, R.J.; Gebre-Mariam, M.; Hagemann, S.G.; Robert, F. Orogenic gold deposits: A proposed classification in the context of their crustal distribution and relationship to other gold deposit types. Ore Geol. Rev. 1998, 13, 7-27.

21. Hart, C.J.R.; Goldfarb, R.J. Distinguishing intrusion-related from orogenic gold systems. In Proceedings of the 2005 New Zealand Minerals Conference, Auckland, New Zealand, 13-16 November 2005; pp. 125-133.

22. Billström, K.; Eilu, P.; Martinsson, O.; Niiranen, T.; Broman, C.; Weihed, P.; Wanhainen, C.; Ojala, J. IOCG and related mineral deposits of the northern Fennoscandian shield. In Hydrothermal Iron Oxide Copper-Gold and Related Deposits; Porter, T.M., Smith, M.P., Coppard, J., Herrington, R., Eds.; PGC Publishing: Adelaide, Australia, 2011; Volume IV, pp. 381-414.

23. Mattson, B.; Lundstam, E. Bedrock Sampling and Diamond Drilling in Åkerberg, Skellefte Field, 1995-1998; Boliden Internal Report GP 99009; Boliden Mineral AB: Boliden, Sweden, 1999; pp. 1-10.

24. Bergström, U. Marginal basin magmatism in an ancient volcanic arc: Petrology of the Palaeoproterozoic Malå-group basalts, Skellefte District, Northern Sweden. GFF 1997, 119, 151-157.

25. Kathol, B.; Weihed, P. Description of Regional Geological and Geophysical Maps of the Skellefte District and Surrounding Areas; Geological Survey of Sweden: Uppsala, Sweden, 2005.

26. Wilson, M.R.; Hamilton, P.J.; Fallick, A.E.; Aftalion, M.; Michard, A. Granites and proterozoic crustal evolution in Sweden: Evidence from $\mathrm{Sm}-\mathrm{Nd}, \mathrm{U}-\mathrm{Pb}$ and $\mathrm{O}$ systematics. Earth Planet. Sci. Lett. 1985, 72, 376-388.

27. González-Roldán, M.J. Mineralogía, Petrología y geoquímica de Intrusions Sin-volcánicas en el Distrito Minero de Skellefte, Norte de Suecia. Ph.D. Thesis, University of Huelva, Huelva, Spain, 2010. 
28. Bejgarn, T.; Söderlund, U.; Weihed, P.; Årebäck, H.; Ernst, R.E. Palaeoproterozoic porphyry $\mathrm{Cu}-\mathrm{Au}$, intrusion-hosted $\mathrm{Au}$ and ultramafic $\mathrm{Cu}-\mathrm{Ni}$ deposits in the Fennoscandian Shield: Temporal constraints using U-Pb geochronology. Lithos 2012, in press.

29. Lundström, I. Description to the rock map sheet $23 \mathrm{~K}$ Boliden SO. Geol. Surv. Swed. 2000, 113, 243-248.

30. Årebäck, H.; Mattsson, B.; Wasström, A. Geochemical Characteristics of Granitoids in the Skellefte District and Surrounding Areas: Development for Au Exploration; Boliden Internal Report GP2005-25; Boliden Mineral AB: Boliden, Sweden, 2004; pp. 1-15.

31. Lundström, I.; Persson, P.-O.; Bergström, U. Indications of early deformational events in the northeastern part of the Skellefte field. Indirect evidence from geologic and radiometric data from the Stavaträsk-Klintån area, Boliden map-sheet. Geol. Surv. Swed. C 1999, 831, 52-69.

32. Teertstra, D.K.; Černý, P.; Langhof, J.; Smeds, S.-A.; Grensman, F. Pollucite in Sweden: Occurrences, crystal chemistry, petrology and subsolidus history. Geol. Fören. Stockh. Förh. 1996, 118, 141-150.

33. Grensman, F.; Langhof, J. Åkerberget: Guldgruva med litiumpegmatite. Stein 1991, 18, 20-22.

34. Romer, R.L.; Smeds, S.-A. Implications of U-Pb ages of columbite-tantalites from granitic pegmatites for the Palaeoproterozoic accretion of 1.90-1.85 Ga magmatic arcs to the Baltic Shield. Precambrian Res. 1994, 67, 141-158.

35. Weihed, P.; Bergman, J.; Bergström, U. Metallogeny and tectonic evolution of the early Proterozoic Skellefte District, northern Sweden. Precambrian Res. 1992, 58, 143-167.

36. Billström, K. Epigenetic gold along the margin of the Skellefte district, Sweden. In Gold '99 Trondheim: Precambrian Gold in Fennoscandian and Ukrainian Shields and Related Areas: Abstract Volume, Proceeding of Nordic Mineral Resources Symposium, Trondheim, Norway, 4-6 May 1999; Cook, N.J., Sundblad, K., Eds.; Geological Survey of Norway: Trondheim, Norway, 1999; pp. 25-27.

37. Sundblad, K. Metallogeny of gold in the Precambrian of northern Europe. Econ. Geol. 2003, 98, 1271-1290.

38. Eilu, P.; Weihed, P. Fennoscandian shield-orogenic gold deposits. Ore Geol. Rev. 2005, 27, 326-327.

39. Dahlenborg, L. A rock magnetic study of the Akerberg gold deposit, northern Sweden. M.Sc. Thesis, Lund University, Lund, Sweden, 2007.

40. Weihed, J.B. Regional Deformation Zones in the Skellefte and Arvidsjaur Areas; Final Research Report SGU-Project 03-862/93; Geological Survey of Sweden: Uppsala, Sweden, 1997.

41. Rutland, R.W.R.; Skiöld, T.; Page, R.W. Age of deformation episodes in the Palaeoproterozoic domain of northern Sweden, and evidence for a pre-1.9 Ga crustal layer. Precambrian Res. 2001, 112, 239-259.

42. Weihed, P.; Billström, K.; Persson, P.-O.; Weihed, J.B. Relationship between 1.90-1.85 Ga accretionary processes and 1.82-1.80 Ga oblique subduction at the Karelian craton margin, Fennoscandian Shield. GFF 2002, 124, 163-180.

43. Billström, K.; Weihed, P.; Allen, R.L. U-Pb Crustal evolution and temporal constraints on ore formation in the Skellefte ore district and surrounding areas, Sweden - new insights from single zircon U-Pb data. GFF 2012, submitted for publication. 
44. Larson, S.-Å.; Tullborg, E.-L. Why Baltic Shield zircons yield late Paleozoic, lower-intercept ages on U-Pb Concordia. Geology 1998, 26, 919-922.

45. Bodnar, R.J. Introduction to aqueous fluid systems. In Fluid Inclusions: Analysis and Interpretation; Samson, I., Anderson, A., Marshall, D., Eds.; Mineralogical Association of Canada: Ottawa, ON, Canada, 2003; pp. 81-99.

46. Bakker, R.J.; Dubessy, J.; Cathelineau, M. Improvements in clathrate modelling: I. The system $\mathrm{H}_{2} \mathrm{O}-\mathrm{CO}_{2}$ with various salts. Geochim. Cosmochim. Acta 1996, 60, 1657-1681.

47. Claesson, S.; Lundqvist, T. Origins and ages of Proterozoic granitoids in the Bothnian Basin, central Sweden; isotopic and geochemical constraints. Lithos 1995, 36, 115-140.

48. Lundqvist, T.; Vaasjoki, M.; Persson, P.-O. U-Pb ages of plutonic and volcanic rocks in the Svecofennian Bothnian Basin, central Sweden, and their implications for the Palaeoproterozoic Evolution of the Basin. Geol. Fören. Stockh. Förh. 1998, 120, 357-363.

49. Billström, K.; Weihed, P. Age and provenance of host rocks and ores in the Paleoproterozoic Skellefte district, northern Sweden. Econ. Geol. 1996, 91, 1054-1072.

50. Montelius, C.; Billström, K.; Allen, R.L.; Barrett, T.J.; Mortensen, J.K.; Weihed, P.; Svenson, S.-Å. The Genetic Relationship between Rhyolitic Volcanism and $\mathrm{Zn}-\mathrm{Cu}-\mathrm{Au}$ Deposits in the Maurliden Volcanic Centre, Skellefte District, Sweden: Volcanic Facies, Lithogeochemistry and Geochronology. Ph.D. Thesis, Luleå University of Technology, Luleå, Sweden, 2005.

51. Kerrich, R.; King, R. Hydrothermal zircons and baddeleyite in Val d'OrArchean mesothermal gold deposit: Characteristics, compositions, and inclusion properties, with implications for timing of primary gold mineralization. Can. J. Earth Sci. 1993, 30, 2334-2351.

52. Fraser, G.L.; Pattison, D.R.M.; Heaman, L.M. Age of the Ballachulish and Glencoe Igneous Complexes (Scottish Highlands), and paragenesis of zircon, monazite and baddeleyite in the Ballachulish Aureole. J. Geol. Soc. Lond. 2004, 161, 447-462.

53. Billström, K.; Wasström, A.; Bergström, U.; Stigh, J. Age, geochemistry and crustal contamination of the Hemberget mafic-ultramafic layered intrusion in the Knaften area, northern Sweden. In Radiometric Dating Results 5; Bergman, S., Ed.; Sveriges geologiska undersökning: Uppsala, Sweden, 2002; pp. 18-30.

54. Thomas, R.; Webster, J.D.; Davidson, P. Understanding pegmatite formation: The melt and fluid inclusion approach. In Melt Inclusions in Plutonic Rocks; Webster, J.D., Ed.; Mineralogical Association of Canada: Ottawa, ON, Canada, 2006; Chapter 9, pp. 189-210.

55. De Assis Janasi, V.; Antenor Faria, C.; de Freitas, V.A.; Farias Vlach, S.R. Silicic segregations in subvolcanic intrusions: Clues to the origin of bimodal basalt-rhyolite associations in the northern Paraná magmatic province? In Proceeding of IV Simpósio de Vulcanismo e Ambientes Associados, Foz do Iguaçu, Brazil, 11 April 2008.

56. Williams-Jones, A.E.; Heinrich, C.A. Vapor transport of metals and the formation of magmatic-hydrothermal ore deposits. Econ. Geol. 2005, 100, 1287-1312.

57. Heinrich, C.A.; Driesner, T.; Stefansson, A.; Seward, T.M. Magmatic vapor contraction and the transport of gold from the porphyry environment to epithermal ore deposits. Geology 2004, 32, 761-764.

58. Herrington, R.J.; Wilkinson, J.J. Colloidal gold and silica in mesothermal vein systems. Geology 1993, 21, 539-542. 
59. Shelton, K.L.; So, C.-S.; Chang, J.S. Gold-rich mesothermal vein deposits of the Republic of Korea: Geochemical studies of the Jungwon gold area. Econ. Geol. 1988, 83, 1221-1237.

60. Cliff, D.C.; Morávek, P. The Mokrsko gold deposit, central Bohemia, Czech Republic, In Mineral Deposits: From Their Origin to Their Environmental Impacts; Pasava, J., Kribek, B., Zák, S., Eds.; Balkema: Rotterdam, the Netherland, 1995; pp. 105-108.

61. Boiron, M-C.; Barakat, A.; Cathelineau, M.; Banks, D.A.V.; Durisova, J.; Morávek, P. Geometry and P-V-T-X conditions of microfissural ore fluid migration: the Mokrsko gold deposit (Bohemia). Chem. Geol. 2001, 173, 207-225.

62. Maloof, T.; Baker, T.; Thompson, J. The Dublin gulch intrusion-hosted gold deposit, Tombstone plutonic suite, Yukon territory, Canada. Miner. Deposita 2001, 36, 583-593.

63. Stephens, J.R.; Mair, J.L.; Oliver, N.H.S.; Hart, C.J.R.; Baker, T. Structural and mechanical controls on intrusion-related deposits of the Tombstone Gold Belt, Yukon, Canada, with comparisons to other vein-hosted ore-deposit types. J. Struct. Geol. 2004, 26, 1025-1041.

64. Lefebure, D.V.; Hart, C. Plutonic-related Au quartz veins \& veinlets (L02). In Selected British Columbia Mineral Deposit Profiles: Volume 2, Metallic Deposits; Lefebure, D.V., Hõy, T., Eds.; Open file (British Columbia. Geological Survey Branch) 1996-13; British Columbia, Energy and Minerals Division, Geological Survey Branch: Victoria, BC, Canada, 1996.

65. Groves, D.I.; Goldfarb, R.J.; Robert, F.; Hart, C.J.R. Gold deposits in metamorphic belts: Overview of current understanding, outstanding problems, future research and exploration significance. Econ. Geol. 2003, 98, 1-29.

66. Whitehouse, M.J.; Kamber, B.; Moorbath, S. Age significance of U-Th-Pb zircon data from early Archaean rocks of west Greenland-A reassessment based on combined ion-microprobe and imaging studies. Chem. Geol. 1999, 160, 201-224.

67. Stacey, J.S.; Kramer, J.D. Approximation of terrestrial lead isotope evolution by a two-stage model. Earth Planet. Sci. Lett. 1975, 26, 207-221.

68. Ludwig, K.R. User's Manual for Isoplot/Ex Version 2.2. A Geochronological Toolkit for a Microsoft Excel; Berkeley Geochronology Center: Berkeley, CA, USA, 2000.

69. Wiedebeck, M.; Allé, P.; Corfu, F.; Griffin, W.L.; Meier, M.; Oberlie, F.; von Quadt, A.; Roddick, J.C.; Spiegel, W. Three natural zircon standards for U-Th-Pb, Lu-Hf trace element and REE analysis. Geostand. Newsl. 1995, 19, 1-23.

70. Söderlund, U.; Johansson, L. A simple way to extract baddeleyite $\left(\mathrm{ZrO}_{2}\right)$. Geochem. Geophys. Geosyst. 2002, 3, 1014-1010.

71. Jaffey, A.H.; Flynn, K.F.; Glendenin, L.E.; Bentley, W.C.; Essling, A.M. Precision measurement of half-lives and specific activities of ${ }^{235} \mathrm{U}$ and ${ }^{238} \mathrm{U}$. Phys. Rev. 1971, 4, 1889-1906.

72. Smith, J.V. En échelon sigmoidal vein arrays hosted by faults. J. Struct. Geol. 1996, 18, 1173-1179.

73. Tomkins, A.G.; Mavrogenes, J.A. Mobilization of gold as a polymetallic melt during pelite anatexis at the Challenger deposit, south Australia: A metamorphosed Archean gold deposit. Econ. Geol. 2002, 97, 1249-1271.

(C) 2012 by the authors; licensee MDPI, Basel, Switzerland. This article is an open access article distributed under the terms and conditions of the Creative Commons Attribution license (http://creativecommons.org/licenses/by/3.0/). 